\title{
Graptolite biostratigraphy of the Lower Silurian (Llandovery) shelf deposits of the Western Iberian Cordillera, Spain
}

\author{
JUAN CARLOS GUTIÉRREZ-MARCO* \& PETR ŠTORCH† \\ * Instituto de Geología Económica CSIC-UCM, 28040 Madrid, Spain \\ $\dagger$ Institute of Geology AS CR, Rozvojová 135, Praha 6, 16500, Czech Republic
}

(Received 28 November 1996; accepted 12 June 1997)

\begin{abstract}
Eight Lower Silurian graptolite biozones (triangulatus, convolutus, linnaei, turriculatus, crispus, griestoniensis, tullbergi and spiralis) and three subzones (runcinatus-gemmatus, palmeus and hispanicus) have been recognized in the Sierra Menera, Nevera, and Tremedal massifs in the Castilian Branch of the Iberian Cordillera (Western Iberian Cordillera). Early Silurian, Rhuddanian low-diversity normalograptid faunas are also present and these, together with the rich graptolite faunas of the Aeronian triangulatus and convolutus biozones, come from black, shaly intercalations within the quartzose sandstones of the upper part of the Los Puertos Quartzite. Telychian graptolite biozones have been recognized in the succeeding black-shale sequence of the Bádenas Formation. Diachroneity of the transition from sandstones to black shales is dated by graptolites. It ranges from about the base to at least the top of the linnaei Biozone. We suggest that the Lower Silurian black shales of the Western Iberian Cordillera were deposited in a shallow, shelf environment, not much deeper than that of presumably storm-influenced sandstones of the Los Puertos Quartzite.
\end{abstract}

\section{Introduction}

Silurian sedimentary rocks, particularly black shales, are widely distributed in the Variscan basement of the Iberian Peninsula (Spain and Portugal). Silurian fossils (mainly graptolites) have been listed in many papers on the geology of the region (see Truyols \& Julivert, 1983, for references). However, to date there has been little detailed biostratigraphic work.

In the Western Iberian Cordillera (northeastern Spain), Verneuil \& Collomb (1853) and Vilanova y Piera (1870) discovered the Silurian graptolitic shales and nodules with nautiloids and bivalves at some of the localities (Checa, Orihuela del Tremedal and Torres de Albarracín) mentioned in this paper. Much additional data was later collected from the exposures of Llandovery black shales around Albarracín (Castel, 1881; Cortázar, 1885; Calvo, 1895; Dereims, 1898; Kindelán \& Ranz, 1918; Tricalinos, 1928; Lotze, 1929; Philippot \& Riba, 1952; Riba Arderiú, 1959; L. Greiling, unpub. manus., Univ. Heidelberg, 1960; Hernández Sampelayo, 1960; Trurnit, 1967; Lendínez González et al. 1981 and Portero, 1983); from the Llandovery shales in the vicinity of the Sierra Menera iron mines (Kindelán \& Ranz, 1918; Bargalló, 1928; Menéndez Puget, 1928; Jordana y Soler, 1935; Hernández Sampelayo, 1960; P. Herranz Araújo, unpub. Lic. thesis, Univ. Madrid, 1965, 1968; J. Hartleb, unpub. diss., Univ. Heidelberg, 1969; Villena, 1976 and Bascones Alvira, Martín Herrero \& La Moneda, 1982); from the Llandovery and Wenlock of the Serranía de Cuenca (Viallard \& Philippot, 1967; Portero, Olivé \& Ramírez del Pozo, 1975); and from the Ludlow black shales near Molina de Aragón (Sacher, 1966; J. Hartleb, unpub. diss., Univ. Heidelberg, 1969).

About sixty graptolite species and subspecies were recorded by previous authors, coming from sixteen Llandovery, one Wenlock and two Ludlow localities. Only two authors included descriptions or figures: Jordana y Soler (1935) included a photograph of a straight monograptid in subscalariform view, originally identified as Monograptus priodon; and Hernández Sampelayo (1960) included about 70 sketch camera lucida drawings of the graptolites from the Western Iberian Cordillera. The 'new' species and varieties (Monograptus fimbriatus distans, M. fimbriatus minima, M. hispanus-communis, M. hispanus-rostratus, M. marri distans, Mesograptus vertebralis, Diversograptus griegosi-communis and Climacograptus setiles) were not described and illustrated adequately and housing of the figured specimens is unknown. For this reason we propose that these taxa are 'nomina nuda'. In every case, the published graptolite lists need thorough revision, particularly those claiming the co-occurrence of species elsewhere known from entirely different levels (that is, Parapetalolithus palmeus with Neodiversograptus nilssoni, Stimulograptus sedgwickii with Retiolites geinitzianus, Monograptus lobiferus with Saetograptus chimaera). These reflect erroneous taxonomic identifications provided by authors not specialized in graptolite research, combined with the influence of some of Philippot's ideas (e.g. 1950) concerning 'widely observed admixture' among southwestern European Ordovician and Silurian graptolite faunas, involving species coming from different graptolite biozones. 
This paper aims to review the Llandovery graptolite faunas and biostratigraphy of the Western Iberian Cordillera. The new, precise data obtained by bed-by-bed sampling, as well as the critical re-evaluation of the data published by the previous authors, will contribute to increased precision in the worldwide correlation of Llandovery strata using graptolites.

\section{Geological setting}

The Iberian Cordillera is a part of the European Alpine Belt, running with a general northwest-southeast orientation to the northeast of the Hesperian Massif, which is the largest Variscan block formed of Precambrian and Palaeozoic basement in the Iberian Peninsula (Fig. 1).

The Iberian Cordillera is currently subdivided into two principal geographic and geological units, named the Aragonese Branch, that is, the Celtiberian or Eastern Iberian Cordillera and the Castilian Branch, that is, the Hesperian or Western Iberian Cordillera respectively (Figs 1, 2). The Eastern Iberian Cordillera comprises several large Palaeozoic outcrops (basal Cambrian to Permian) referred to the so-called Iberian Chains and surrounded by Cenozoic basins. The Western Iberian Cordillera is formed by large Alpine antiforms composed of Mesozoic rocks. In the core of these antiforms are scattered occurrences of the Variscan basement, ranging in age from Lower Ordovician to Carboniferous.

The two principal Mesozoic structures of the Western Iberian Cordillera, in which the majority of the Palaeozoic rocks crop out, are the Sierra de Albarracín Antiform (to the northeast) and the Serranía de Cuenca Antiform (to the southwest). The corresponding core areas which exhibit the Variscan basement were designated as 'massifs' in the Spanish geological literature. Silurian deposits and fossils have been recorded in the Aragoncillo, Sierra Menera, Santa María del Espino, Ciruelos-Teroleja, Nevera, Tremedal and Sierra Carbonera massifs (Albarracín Antiform), and the Valdemeca, Cañete and Frontón del Cerro-Minas de Henarejos massifs (Serranía de Cuenca Antiform) (structural terminology following Capote \& González Lodeiro, 1983).

The Silurian stratigraphy of the Western Iberian Cordillera has never been studied in detail, although a general stratigraphic scheme was published in the last century (Cortázar, 1885; Dereims, 1898). This was modified by Lotze (1929) and Riba Arderiú (1959), and more recently checked during work on the official geological map of Spain (1:50000, sheet numbers 488, 489, 514, $515,540,541,565,566,611$ and 636) of the Second Series, published between 1975 and 1983.

In general, the Silurian succession comprises a sparsely fossiliferous lower unit (the Los Puertos Quartzite), which rests unconformably upon late Ordovician glaciomarine deposits, and an upper unit composed of a thick sequence of graptolitic black shales (the Bádenas Formation) with subordinate sandstones.

\section{Sections studied}

The best sections for Llandovery graptolite biostratigraphy occur in the Nevera, Tremedal, and Sierra Menera massifs of the Sierra de Albarracín Anticlinorium.

Two measured sections occur along the road between Checa and Orea, in the western part of the Nevera Massif, in the province of Guadalajara (A and B in Fig. 1). The more complete one (Checa section, Fig. 3) shows a continuous Telychian succession in which seven graptolite biozones and subzones are identified. The sequence has been studied at a large exposure, $1.15 \mathrm{~km}$ west of the church in the town of Checa on both sides of the road (A in Fig. 1, grid references 30TXK603.53/4494.18 - base, 30TXK 603.40/4494.42 - top, sheet no. 540), which yields abundant and well-preserved graptolites. It most probably corresponds to the famous fossil locality 'Checa' mentioned by earlier authors (Verneuil \& Collomb, 1853; Castel, 1881, Kindelán \& Ranz, 1918) and partly reviewed by Riba Arderiú (1959; pp. 50-2). The second section (B in Figs 1, 3, Orea-Checa road section) is exposed by a road

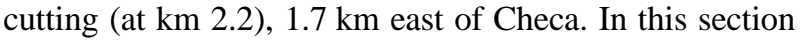
(grid reference 30TXK604.15/4494.02, sheet no. 540) we recorded four biozones (?Rhuddanian, Aeronian and lower Telychian) in the transitional beds between the Los Puertos Quartzite and the Bádenas Formation.

Three sections are located in the western part of the Tremedal Massif (C-E in Fig. 1), along the TE-903 road between Orihuela del Tremedal and Noguera (province of Teruel). The first (C in Figs 1, 3) is $2.6 \mathrm{~km}$ southwest of Orihuela del Tremedal, between $\mathrm{km} 37.05$ and 37.1 (grid reference 30TXK613.1/4487.7, sheet no. 540), and corresponds to the classic locality 'Orihuela' mentioned by Verneuil \& Collomb (1853), Vilanova y Piera (1870), Cortázar (1885), Dereims (1898), Kindelán \& Ranz (1918), Lotze (1929) and Riba Arderiú (1959). The last author gave a detailed account of the locality, and recognized six arbitrary graptolite levels showing a general 'mixture' of index species from several graptolite zones. Detailed examination of the section (Fig. 3) allowed us to recognize four Telychian graptolite biozones, although the stratigraphic succession has not been fully reconstructed due to tectonic disruption of the sequence. The second section lies to the south on the same road, approximately $7.5-9.2 \mathrm{~km}$ south-southeast of Orihuela del Tremedal and $4.3 \mathrm{~km}$ northwest from Noguera, between $\mathrm{km} 30.4$ and 31.1 (D in Figs 1, 3). Grid references are 30TXK614.8/4482.37 (base of section) and 30TXK615.0/4481.76 (top of section) on the map sheet no. 565. Four different graptolite assemblages were recognized within the upper part of the Los Puertos Quartzite up to the lowermost part of the Bádenas Formation (Fig. 3). Graptolites in the quartzite unit from this exposure were mentioned by L. Greiling (unpub. manus., Univ. Heidelberg, 1960) and Trurnit (1967). The third section is in a small exposure $3 \mathrm{~km}$ westnorthwest of Noguera on the same road, at $\mathrm{km} \mathrm{28.9,} \mathrm{east}$ of El Castillo point ( $\mathrm{E}$ in Fig. 1, grid reference 30TXK616.15/4480.95, sheet no. 565). The graptolites 
are confined to a thin bed of shales within the upper part of the Los Puertos Quartzite. This shale intercalation was mentioned by Riba Arderiú (1959, p. 57) and assigned to the overlying black shale Bádenas Formation, but later reassigned by Trurnit (1967) to its present stratigraphic position.

In the El Pobo Anticline, which forms the northwestern extension of the Sierra Menera Massif, graptolitic black

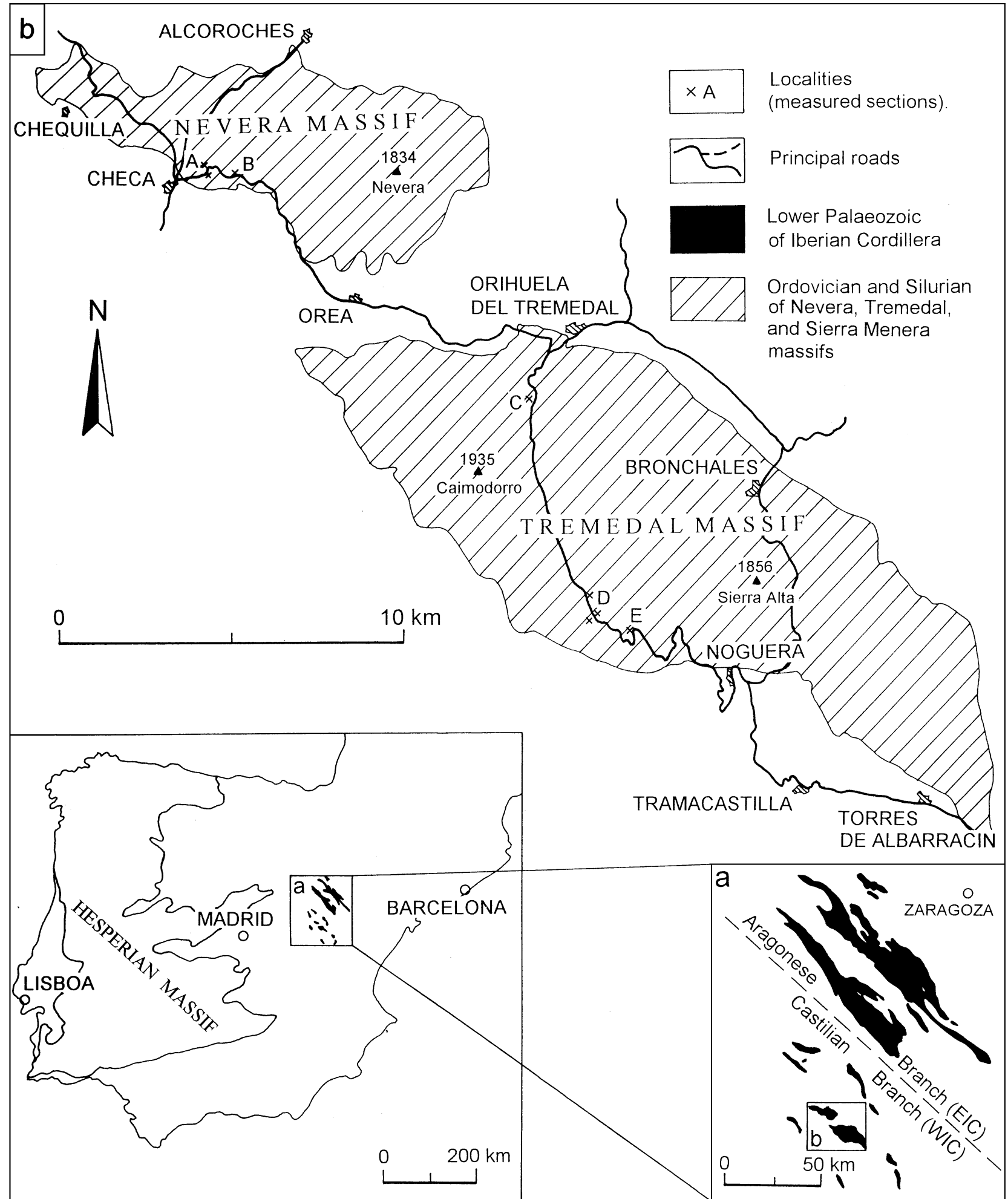

Figure 1. Lower Palaeozoic of the Iberian Cordillera, with location of the sections described herein. (a) Inset map showing location of the Nevera and Tremedal massifs (b) in the western part (Castilian Branch) of the Iberian Cordillera; (b) location of the graptolite bearing composite sections of Nevera and Tremedal massifs: A - Checa, B - Orea-Checa roadcut section, C - Orihuela del Tremedal roadcut section ( $\mathrm{km} \mathrm{30.4-31.1),} \mathrm{D} \mathrm{-} \mathrm{Orihuela} \mathrm{del} \mathrm{Tremedal} \mathrm{roadcut} \mathrm{section} \mathrm{(km} \mathrm{37.0-37.1),} \mathrm{E} \mathrm{-} \mathrm{El} \mathrm{Castillo.} \mathrm{WIC} \mathrm{-} \mathrm{Western} \mathrm{Iberian}$ Cordillera; EIC - Eastern Iberian Cordillera. 


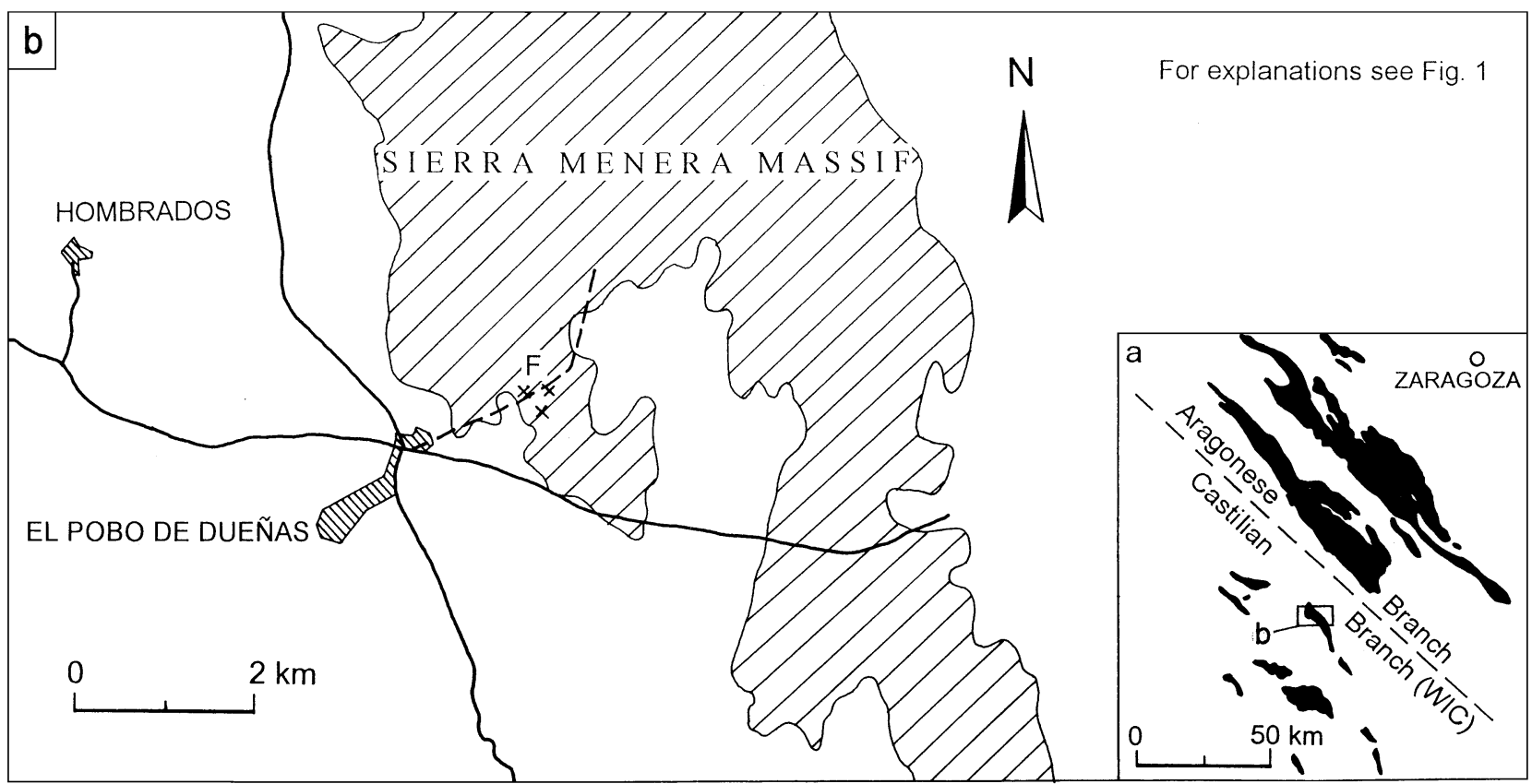

Figure 2. Location of the El Pobo de Dueñas composite section (F) in the northwestern part of the Sierra Menera Massif. (a) Inset map showing location of the massif; (b) in the Castilian Branch of the Iberian Cordillera. WIC - Western Iberian Cordillera.

shales of the Bádenas Formation occur in several exposures north and northeast of El Pobo de Dueñas (Guadalajara province). The most fossiliferous exposure lies to the north of $\mathrm{km} \mathrm{220-221} \mathrm{of} \mathrm{the} \mathrm{N-211} \mathrm{highway,}$ between $2.5-3 \mathrm{~km}$ northeast of the church in El Pobo (F in Fig. 2, Fig. 3 - El Pobo de Dueñas section, grid references 30TXL616.1-5/4516.4-7, sheet no. 515). There we recognized three Middle and Upper Telychian graptolite biozones in a rather tectonized sequence. The uppermost levels are remarkable owing to the great abundance of fossiliferous nodules, known and illustrated since the time of Torrubia (1754). Graptolite findings from the 'El Pobo' locality are referred to also by Verneuil \& Collomb (1853), Kindelán \& Ranz (1918), Hernández Sampelayo (1960), Herranz Araújo (P. Herranz Araújo, unpub. Lic. thesis, Univ. Madrid, 1965, 1968), Hartleb (J. Hartleb, unpub. diss., Univ. Heidelberg, 1969), Villena (1976) and Bascones Alvira, Martín Herrero \& La Moneda (1982).

\section{Stratigraphy and depositional environment}

The late Ordovician is represented by the well-known glaciomarine diamictites of the Orea Shale in both the Western and Eastern Iberian cordilleras. This unit is up to $80 \mathrm{~m}$ thick, formed of silty shale with common unsorted quartz and sedimentary rock (sandstone, siltstone, limestone) fragments, larger pebbles and even blocks and boulders (dropstones). It was described by Fortuin (1984) and Robardet \& Doré (1988). Evidence, although often indirect, for the Hirnantian age of the Upper Ordovician diamictites here and elsewhere in peri-Gondwanan Europe has been summarized by Brenchley et al. (1991). The Hirnantian diamictites are separated from the Lower
Silurian black shales by massive quartzose sandstones ('White' or 'Valentian' Quartzites of German geologists), a unit widespread in the Ordovician-Silurian shelf sequences of the Iberian Peninsula (Truyols \& Julivert, 1983; San José et al. 1992).

\section{4.a. Los Puertos Quartzite}

In the Western Iberian Cordillera the sandstone unit separating the Upper Ordovician glaciomarine diamictites and Lower Silurian black shales has been named the Los Puertos Quartzite by Portero (1983). The formation lies with a prominent erosional unconformity over the diamictites of the Orea Shale. It is formed of thick- to medium-bedded quartzose sandstones. The thickness of the Los Puertos Quartzite varies greatly, from $1.8 \mathrm{~m}$ (Checa section) to a maximum of about $80 \mathrm{~m}$ (Noguera section), often within a short distance. The mean thickness is $20-40 \mathrm{~m}$ in the whole Western Iberian Cordillera. The upper part of the Los Puertos Quartzite is composed of medium- to thin-bedded sandstones with common ripple marks, wave-ripple cross-laminations, and vertical burrows of Skolithos type. Fortuin (1984) reported common scour-and-fill structures. These sandstones are intercalated with several beds of black shale in which graptolites have been found. These provide unquestionable evidence for the early and mid-Llandovery age of most of this sequence.

The earliest intercalation, composed of grey silty shale, locally further interbedded by one or more sandy layers, has been recorded in most of the examined sections. It contains graptolites suggesting the early Llandovery acuminatus, vesiculosus and cyphus biozones. Stratigraphically higher 
A

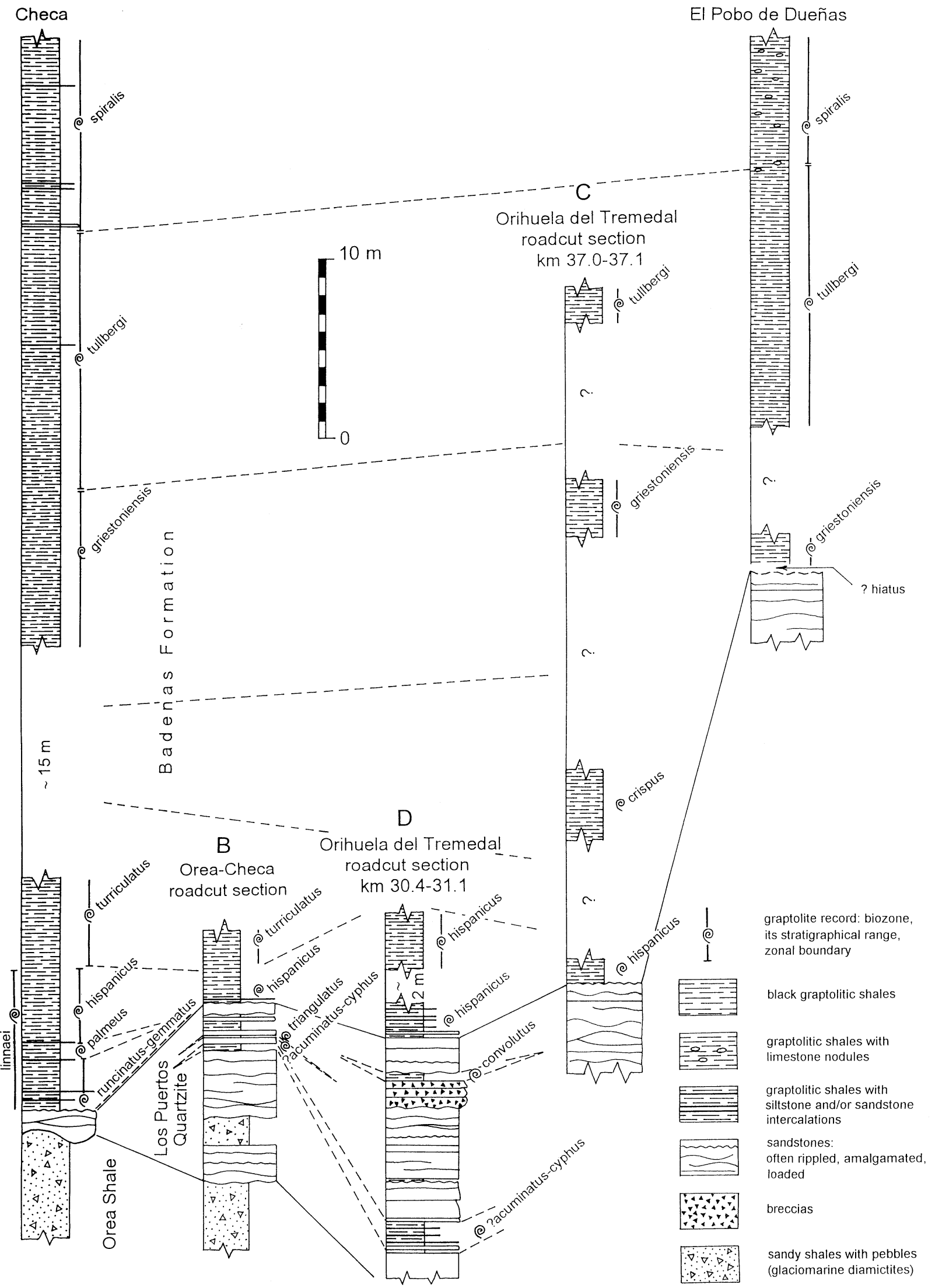

Figure 3. Lithostratigraphic and biostratigraphic correlation of the principal sections in the Western Iberian Cordillera. Simplified logs show the Checa (A) and Checa-Orea (B) sections from the Nevera Massif, two composite roadcut sections from the Tremedal Massif-Orihuela del Tremedal, km 30.4-31.1 (D) and km 37.0-37.1 (C), and the El Pobo de Dueñas Section (F) from the Sierra Menera Massif. Biostratigraphic correlation is marked by dotted lines, correlation of the lithostratigraphic boundaries by solid lines. 
intercalations are composed of black shales which yielded graptolites of the mid-Llandovery triangulatus (Fig. 3, loc. B) and convolutus (Fig. 3, loc. D) biozones respectively. Rapid lateral changes in the thickness of the Los Puertos Quartzite, the often deeply erosional bases of the thicker sandstone beds, common wave-ripples and vertical burrows indicate that deposition probably occurred under shallowwater, storm-influenced conditions. Hummocky cross-stratification has not yet been recorded for certain, although some sandstone beds show poorly visible cross-lamination resembling hummocky cross-stratification. The complete absence of black shales in some sections (e.g. at the Checa section, loc. A), close to sections in which several graptolite-bearing black-shale interbeds are present (Checa-Orea road cutting, loc. B), can be explained by subsequent erosion of black-shale levels and amalgamation of the sandstone beds. Amalgamated sandstone beds, well seen in the Checa section for instance, belong, along with hummocky cross-stratification, among the most common structures in storm wave-influenced shelf sandstones. Sandstones which occur in about the middle part of the underlying Orea Shale were also regarded as tempestites by Fortuin (1984). The quartzose sandstones, equal to Los Puertos Quartzite (Truyols \& Julivert, 1983; San José et al. 1992), although of varied thickness, are considerably widespread over the Ordovician-Silurian boundary sequences of the broad, storm-dominated (according to Brenchley, Romano \& Gutiérrez-Marco, 1986) shelf of the Iberian Peninsula.

\section{4.b. Bádenas Formation}

This formation was defined by Carls \& Gandl (1967) in the 'Eastern Iberian Chains' (Aragonese Branch or Eastern Iberian Cordillera), and consists of predominantly black shales with frequent silty intercalations, and with two main sandstone units recognized in the upper part of the formation and dividing it into five stratigraphic members. The total thickness of the Bádenas Formation varies between 850 and $1400 \mathrm{~m}$ in the Eastern Iberian Cordillera, this thickness being exceptional for a single unit in the Silurian of the Iberian Peninsula.

Fossils are rare in the Eastern Iberian Cordillera, even in the lower black-shale member (400-800 m thick s3a unit or 'untere tonreiche folge' in the sense of Carls \& Gandl, 1967). Sparse occurrences of Llandovery and Wenlock graptolites, organic microfossils and a very rare assemblage of shallow water brachiopods and trilobites have been noted by Lotze (1929), and in unpublished studies by P. Carls (unpub. diss., Univ. Würzburg, 1965), J. Keller (unpub. Diplomarb., Univ. Würzburg, 1981), A. Kistner (unpub. Diplomarb., Univ. Würzburg, 1981) and G. Wehner (unpub. Diplomarb., Univ. Würzburg, 1984). The upper sandstone and shaly members of the Bádenas Formation were referred to the Ludlow on the basis of the conodont, brachiopod, trilobite and graptolite faunas reported by Carls \& Gandl (1967), Gandl (1972) and Carls (1974).

In the Western Iberian Cordillera the Bádenas
Formation crops out in a very discontinuous manner (and commonly with layers missing due to erosion). It is the youngest preserved unit of the Lower Palaeozoic succession of the Castilian Branch (Western Iberian Cordillera). Further, the Bádenas Formation appears to be considerably condensed in the Western Iberian Cordillera in comparison with its type area in the Eastern Iberian Cordillera. Fossils, however, are much more common, diverse and well preserved in the Western Iberian Cordillera, namely those preserved in black shales.

In the area studied herein, the black-shale Bádenas Formation, c. $60 \mathrm{~m}$ thick, rests conformably on the Los Puertos Quartzite and corresponds in age to the lowermost shale member of the Bádenas Formation of the Eastern Iberian Cordillera. The rich graptolite faunas reviewed herein are all Llandovery.

The base of the black-shale sequence is sharp, although some thin (a few centimetres thick), commonly rippled sandstone and siltstone beds have been recorded in the lowermost part of the formation, and rarely even higher, in the tullbergi and spiralis biozones.

The base of the Bádenas Formation is somewhat diachronous. The degree of diachroneity of its contact with the underlying quartzites is documented by means of graptolites in this paper. At the Checa section (Fig. 3, loc. A) the basal black shales of the formation belong to the lower part of the linnaei Biozone (runcinatus-gemmatus Subzone, earliest Telychian). Elsewhere in the Nevera and Tremedal massifs (Fig. 3, locs B-D) the black shales begin in the upper part of the linnaei Biozone (hispanicus Subzone) or in the succeeding turriculatus Biozone. In the El Pobo de Dueñas Anticline (northern Sierra Menera Massif) the black-shale sequence begins in the midTelychian griestoniensis Biozone (Fig. 3, loc. F). At the last mentioned locality, however, the thin ferruginous horizon, noted by Herranz Araújo (1968) at the base of the black-shale sequence, may indicate some hiatus or tectonics at the immediate contact. All available sections terminate in the spiralis Biozone.

Micaceous, silty black shales with fragmented graptolites are common near the base of the Bádenas Formation. At the Checa section many bedding planes are crowded with the long, mostly individual thecae of Rastrites lin$n a e i$, possibly fragmented by wave action. Higher up, the graptolites are well oriented by currents (Fig. 4). At the Checa section (Fig. 3, loc. A) a unimodal WNW-ESE current dominated from about the middle part of the linnaei Biozone until at least the griestoniensis Biozone. Sandy-micaceous laminites with abundant, current-oriented graptolites characterize the lower part of the turriculatus Biozone. The laminites closely resemble Lower Llandovery black contourites of the Prague Basin (Oczlon, 1992). In the north of Sierra Menera Massif (El Pobo de Dueñas) the black shales of the spiralis Biozone contain common muddy limestone nodules with threedimensional moulds of graptolites, eurypterids, bivalves and nautiloids. Otherwise the non-graptolite fauna found in the Bádenas Formation is composed of eurypterids, 


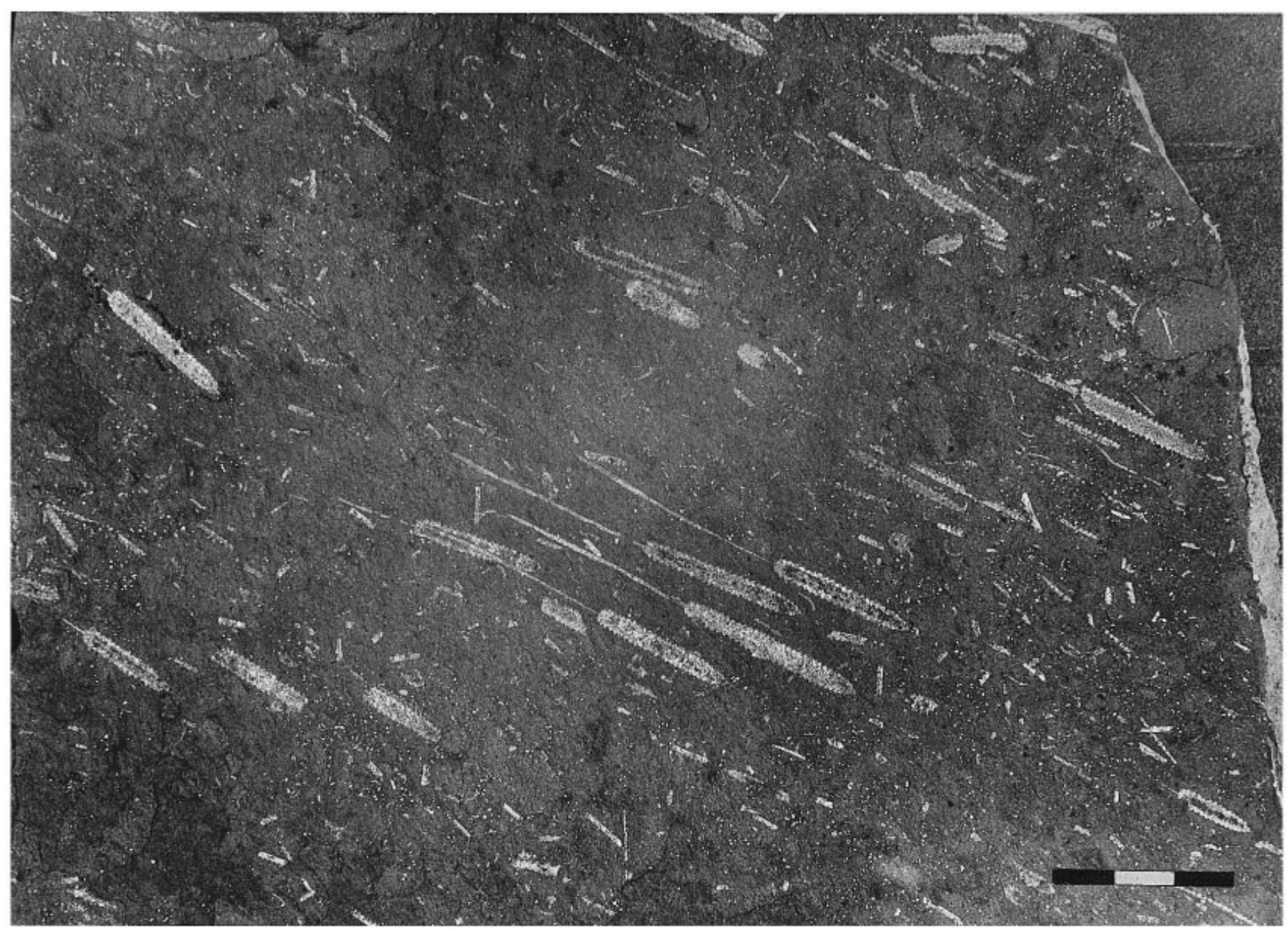

Figure 4. Current oriented rhabdosomes, largely of Parapetalolithus palmeus (Barrande), from the palmeus Subzone at Checa. Each division of scale bar $=1 \mathrm{~cm}$.

phyllocarids, peltocarids, cornulitids, bivalves, orthoconic nautiloids, rare brachiopods and very rare trilobites. Benthic faunal associations and, frequently, articulated eurypterids have been preserved in situ, without significant transport.

\section{Palaeoecology, biostratigraphy and correlation}

Lower Silurian graptolites are common and are often well preserved in the Western Iberian Cordillera. The assemblages, however, are considerably less diverse than those in Wales, Thuringia and Bohemia. We recognize 86 species, including those left in open nomenclature. We interpret the high-density but low-diversity assemblages as suggesting a shallow, shelf environment in which the Llandovery black shales of the Western Iberian Cordillera were deposited, although the role of cool climate, influenced by a southern, peri-Gondwanan current, cannot be excluded.

The Llandovery (early Silurian) graptolite fauna of the Western Iberian Cordillera appears similar to that of the Sierra Morena (Haberfelner, 1931), the Guadarranque Syncline in Montes de Toledo (Rodríguez-Nüñez, Gutiérrez-Marco \& Sarmiento, 1989) and the eastern part of Sistema Central (personal observations in the
Guadarrama region). However, the large amount of Iberian data published before 1970, mostly faunal lists without figured specimens, needs careful revision as do the monographs by Haberfelner (1931), Hernández Sampelayo (1960), and Romariz (1962, 1969).

Of the well-known graptolite faunas from outside Spain, the graptolite fauna of the Western Iberian Cordillera resembles those listed from Bohemia (Bouček, 1953; Storch, 1994), Germany (Schauer, 1967, 1971), and Scandinavia (Törnquist, 1892, 1907; Bjerreskov, 1975). Many species are common with the Welsh Basin and also Scotland (Rickards, 1976; Loydell, 1991; Loydell \& Cave, 1993; Zalasiewicz, 1994). There are several features, however, specific to the Telychian fauna of the Western Iberian Cordillera. Rastrites (5-6 species) and Parapetalolithus (5-6 species) are rather common and diverse although less so than in Bohemia. Streptograptus is common also and diverse, in contrast with Monoclimacis, which is represented by Mcl. griestoniensis, Mcl. crenulata, and $\mathrm{Mcl}$. sp., the last two of which are very rare and confined to thin levels. Some species (Cochlograptus veles, Pseudoplegmatograptus obesus, Streptograptus exiguus), common and long ranging elsewhere, are rare in the Western Iberian Cordillera. Some other species (Monograptus drepanoformis and Torquigraptus flagellaris), reported as being rare elsewhere, are surprisingly 
common in some levels. Other species are highly characteristic of the Iberian shelf sea (Monograptus sp.n. A from the upper griestoniensis and tullbergi biozones, $M$. sp.n. B from the upper tullbergi and lower spiralis biozones, Pseudoplegmatograptus sp.n. from the linnaei Biozone, Parapetalolithus cf. schaueri-?sp.n. from the crispus-griestoniensis biozones and, probably, some of the streptograptids). Some other species link the Spanish faunas with those of North African pericratonic and intracratonic basins (e.g. Metaclimacograptus cf. asejradi from the linnaei and turriculatus biozones and Paraclimacograptus? flamandi from the crispus-lower tullbergi biozones). Paraclimacograptus brasiliensis, a species widespread in the Gondwanan realm (Brazil, Argentina, Paraguay, Algeria, ?Tunisia and Jordan) was formerly reported also from Spain (e.g. Jaeger, 1976). This species, however, comes from Lower to Mid-Llandovery rocks in South America and Africa (Turner, 1960; Jaeger, 1976; Grahn \& Paris, 1992; Rickards et al. 1996), whereas the Spanish material comes from the Upper Llandovery (mid-Telychian) strata. The Spanish specimens are narrower, and have apertural hoods instead of spines. They are here reassigned to Par? flamandi described by Legrand (1993) from the Middle Telychian of Algeria.

The Telychian assemblages of the Western Iberian Cordillera are marked by the brief, sometimes repeated, appearances of some graptolite species which, perhaps, survived here at the edge of their usual life-habit ( $\mathrm{Mcl}$. crenulata, C. veles, Str. aff. sartorius, $M$. drepanoformis and, to a lesser degree, $O$. spiralis). This may be considered as further indirect evidence for a shallow, shelf environment in the early Silurian of the Western Iberian Cordillera based on recent observations about graptolite depth distribution (Chen, 1990; Cooper, Fortey \& Lindholm, 1991; Lenz et al. 1993). Paskevicius (1986) examined the facial and bathymetric distribution of Telychian graptolites in the East Baltic region. He recorded graptolite faunas similar to the present assemblages of the Bádenas Formation in shallower (according to his interpretation) outer-shelf facies (M. priodon, C. veles, Mcl. griestoniensis, T. spiraloides, T. flagellaris, $O$. spiralis) and higher diversity graptolite faunas from basin-slope facies, whilst the mid- and innershelf facies yielded almost no graptolites.

Mu et al. (1986) and Chen (1990) reported rich graptolite assemblages associated with benthic faunas of B.A. 3-5 (B.A. - benthic assemblage depth zones according to Boucot's 1975 terminology) in the Silurian epicontinental deposits of the Yangtze Platform. In agreement with other authors (Berry \& Boucot, 1972; Lenz \& Chen, 1985; Lenz et al. 1993), they found Retiolites and monograptids of the $M$. priodon group in the shallowest environment, corresponding with the B.A. 2 zone. In the B.A. 3 level they recorded the appearance of $M c l$. griestoniensis, Mcl. vomerina, and Cor. gregarius. Rich faunas, still corresponding with the epipelagic graptolite fauna in the sense of Cooper, Fortey \& Lindholm (1991), were found at the level of B.A. 4-5. This fauna was enriched with O. spiralis and related forms, C. veles, Rastrites,
Demirastrites, Streptograptus and Spirograptus. Another rich graptolite fauna in association with the shelly fauna of B.A. 4-5 has been recorded from Hyskov in Bohemia (Havlícek \& Storch, 1990). Following the sedimentological criteria applied by Brett, Boucot \& Jones (1993), we consider that the Telychian graptolite fauna of the Bádenas Formation would probably also be consistent with a B.A. 4-5 assignment.

However, the fauna of the black-shale intercalations within the Los Puertos Quartzite, with Rastrites, Demirastrites, Campograptus and other, supposed deeper-water forms, argues against such a simple interpretation. It is probable that 'deeper-water' forms invaded mid- and, perhaps also, inner-shelf areas in the presence of the nutrient-rich, oxygen-depleted waters which resulted in the black-shale sedimentation on the shelf.

Recent data from the Yangtze Platform (Mu et al. 1986; Chen, 1990) and from Bohemia (Storch \& Pasava, 1989; Havlícek \& Storch, 1990) suggest that rich and diverse graptolite faunas inhabited deeper and/or outer shelf environments in cases of favourable shelf-basin topography, water temperature gradient, nutrient supply and organic matter productivity. The present data from the Western Iberian Cordillera suggest that the black-shale facies with rather abundant, though low to moderate diversity, graptolites may have reached even shallower shelf areas.

Despite the low diversity of graptolite assemblages, and the poor representation of the early and middle Llandovery, zonal-index graptolites and some other agediagnostic species of great correlative use are present in the Western Iberian Cordillera. They allow the recognition of eight graptolite biozones and three subzones (triangulatus, convolutus, linnaei, turriculatus, crispus, griestoniensis, tullbergi and spiralis biozones and runcinatus-gemmatus, palmeus and hispanicus subzones). The presence of some others (acuminatus, vesiculosus and cyphus biozones) is probable.

Most of the biozones are treated here as assemblage zones, simply recognized by their characteristic assemblage, and the presence of the index graptolites. Such biozones are either bounded by barren sandstones (triangulatus, convolutus, linnaei biozones) or their boundaries were not sufficiently accessible for study (crispus and griestoniensis biozones). The turriculatus, tullbergi and spiralis biozones are employed as taxon-range zones, defined by the first appearance of the index taxon and characterized by the whole assemblage (see also Koren' et al. 1995). Correlation with other graptolite zonal schemes, established in Wales, Bohemia and Bornholm, is shown in Figure 5.

\section{Graptolite biozones}

\section{6.a. Acuminatus-cyphus Biozone interval}

Above the Upper Ordovician diamictites of the Orea Shale the first graptolites appear in a grey silty shale horizon within the thick-bedded, rippled quartzose sandstones of 


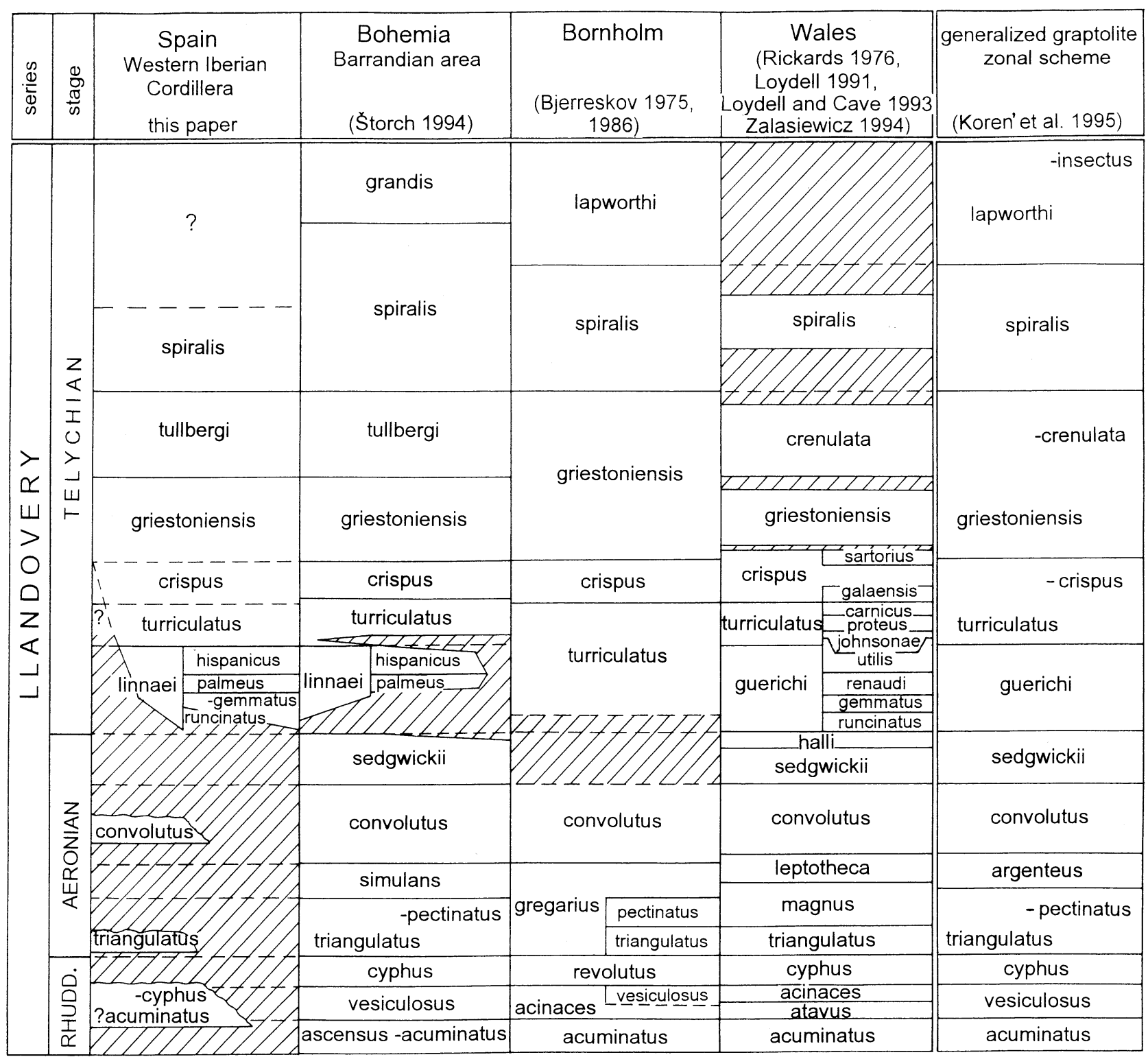

Figure 5. Llandovery graptolite biozones of the Western Iberian Cordillera and correlation with the local schemes of Wales, Bornholm, and Bohemia, and with the generalized zonal scheme introduced by the Subcommission on Silurian Stratigraphy. Symbols: stratigraphically important barren interval indicated by oblique shading, zonal boundary without graptolite record indicated by broken line.

the upper part of the Los Puertos Quartzite. They are recorded from the Orihuela del Tremedal (loc. D, km 31.1), El Castillo (loc. E, km 28.5) and Checa-Orea (loc. B, km 2.2) road cuttings. The silty shale, about $0.5 \mathrm{~m}$ thick, contains uncommon Normalograptus normalis (Lapworth) and rare $N$. angustus (Perner). The two species are known from both the late Ashgill and the early Llandovery in Britain and elsewhere (e.g. Rickards, 1976; Williams, 1983). Our silty shale horizon is assigned tentatively to the Rhuddanian (Lower Llandovery). It corresponds to the graptolite occurrences in the 'Valent-Quartzit' of Nevera and Tremedal massifs mentioned by L. Greiling (unpub. manus., Univ. Heidelberg, 1960), Greiling in Sacher (1966) and Trurnit (1967). Greiling (unpub. manus., Univ. Heidelberg, 1960) reported the presence of 'climacograptids of the Ordovician/Silurian boundary' accompanied by 'several monograptids of the Monograptus (Pristiograptus) cyphus group', not found in the present study. The fossiliferous level is within the upper part of the Los Puertos Quartzite, well above the Upper Ashgill diamictites of the Orea Shale, and is succeeded by another black shale intercalation in which early Aeronian graptolites have been found.

\section{6.b. Triangulatus Biozone}

A moderately diverse graptolite assemblage, indicative of the early Aeronian triangulatus Biozone, has been found in a $5-10 \mathrm{~cm}$ thick black shale intercalation in the upper part of the Los Puertos Quartzite at the Checa-Orea road cutting (Fig. 3, loc. B). It is $30 \mathrm{~cm}$ above the shale intercalation with normalograptids. In addition to the zonal-index graptolite, Demirastrites triangulatus (Harkness), seven other species were identified (Fig. 6): Rastrites longispinus Perner, Coronograptus gregarius 

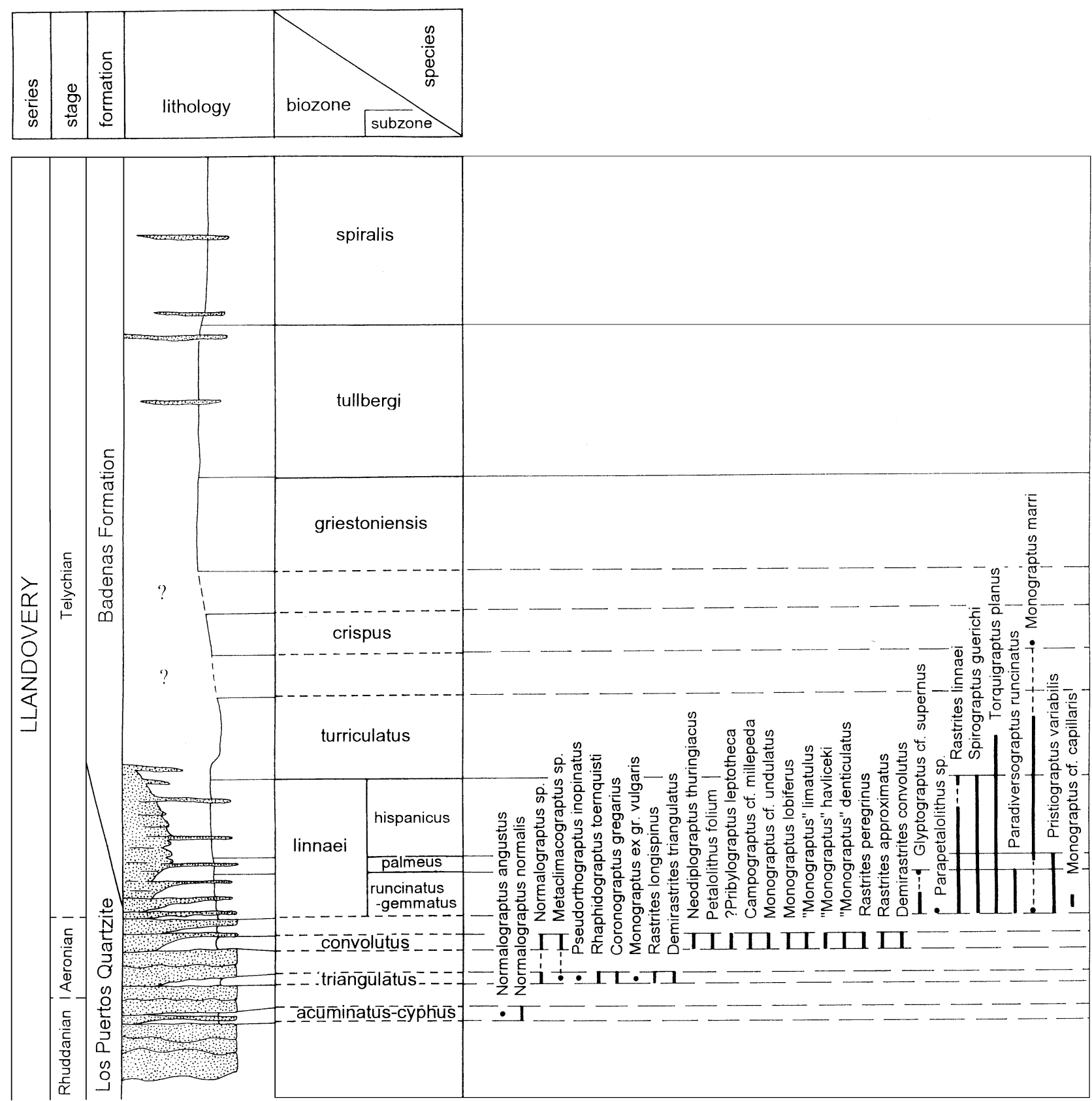

Figure 6. Biostratigraphic ranges of the Llandovery graptolites of the Western Iberian Cordillera recognized in this study. Symbols: a solid line in graptolite range chart indicates the stratigraphic range of the species recorded in the Western Iberian Cordillera sections, a broken line indicates proposed range between stratigraphically distant occurrences, a dot indicates extremely limited and/or rare occurrence. A broken line between biozones indicates that the zonal boundary beds are unknown or represented by barren sandstones.

(Lapworth), Monograptus ex gr. vulgaris Hutt, Pseudorthograptus inopinatus (Boucek), Rhaphidograptus toernquisti (Elles \& Wood), Normalograptus sp. and Metaclimacograptus sp.

\section{6.c. Convolutus Biozone}

The next graptolite assemblage, recorded from another shale intercalation in the uppermost part of the Los Puertos Quartzite, has been assigned to the convolutus
Biozone, of mid-Aeronian age. Graptolites are confined to a $c .50 \mathrm{~cm}$ thick laminated silty shale within the rippled quartzose sandstones in the Orihuela del Tremedal road

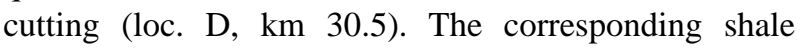
interbed was recorded also at the Checa-Orea road cutting, but without graptolites. At Orihuela del Tremedal the graptolites are common but poorly preserved except for those in some of the less silty laminae (Fig. 7).

The assemblage consists of Demirastrites convolutus (Hisinger) - rare, Rastrites approximatus Perner, $R$. 


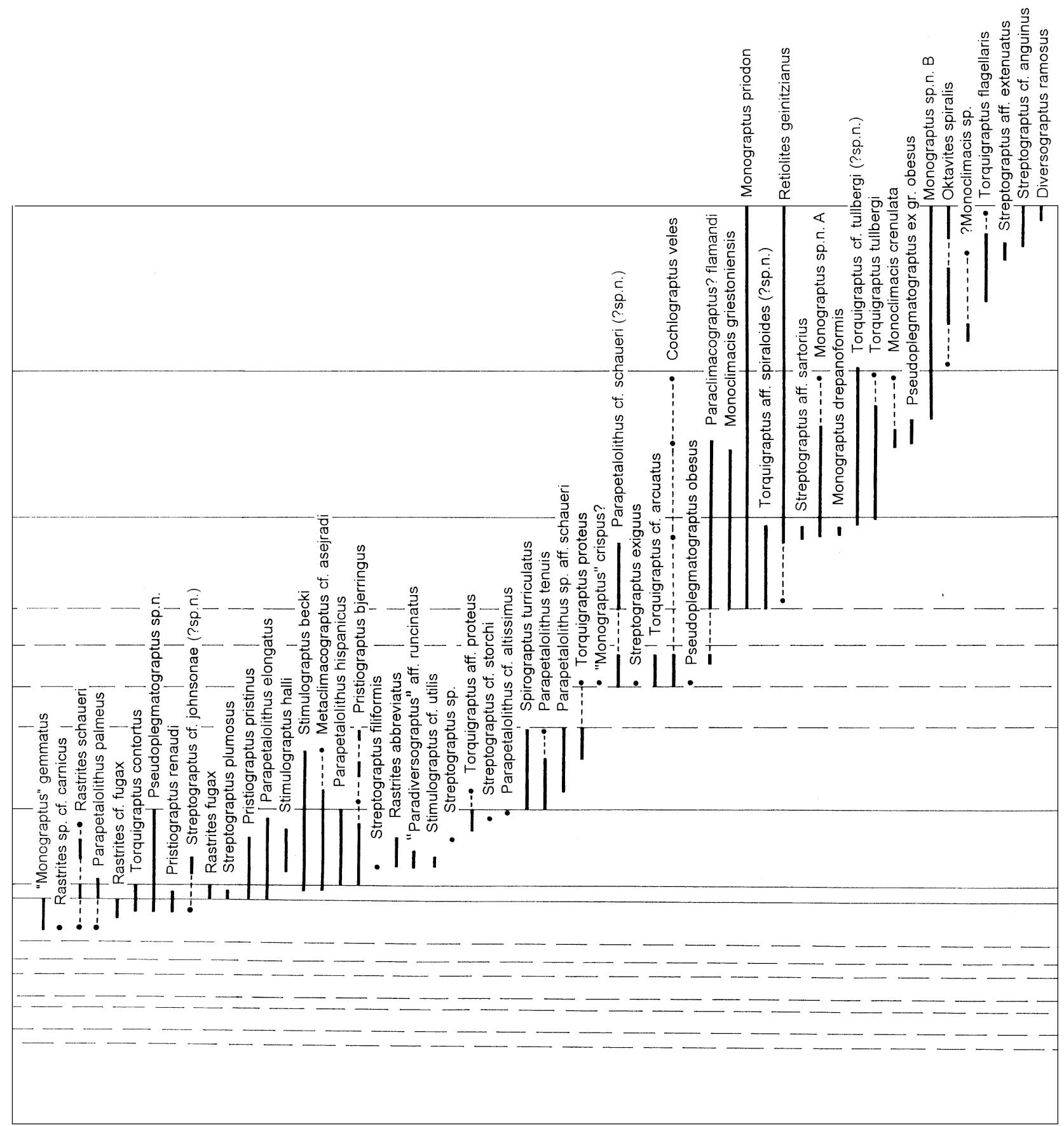

Figure 6. cont.

peregrinus Barrande - common, 'Monograptus' denticulatus Törnquist - common, 'M.' havliceki Storch - rare, 'M.' limatulus Törnquist - rare, Monograptus lobiferus (McCoy) - common, M. cf. undulatus Elles \& Wood, Campograptus cf. millepeda (McCoy), ?Pribylograptus leptotheca (Lapworth), Petalolithus folium (Hisinger), Neodiplograptus thuringiacus (Kirste) - common, Metaclimacograptus sp. and Normalograptus sp.

Although much less diverse, our assemblage resembles markedly the graptolite fauna of the convolutus Biozone of the Barrandian area in Bohemia (Storch, 1994). Even the laminated silty shale resembles the Lower Llandovery sandy-micaceous laminites of the Barrandian area (Storch, 1994).

\section{6.d. Linnaei Biozone}

In the Nevero and Tremedal massifs the black shale Bádenas Formation begins at various points within the early Telychian linnaei Biozone. On the basis of three successive graptolite assemblages the linnaei Biozone can be subdivided into three subzones (in ascending order): runcinatus-gemmatus Subzone, palmeus Subzone and hispanicus Subzone.

\section{6.d.1. Runcinatus-gemmatus Subzone}

The earliest part of the linnaei Biozone, assigned to the runcinatus-gemmatus Subzone, is well exposed in a large outcrop near Checa (loc. A), just above the massive, 


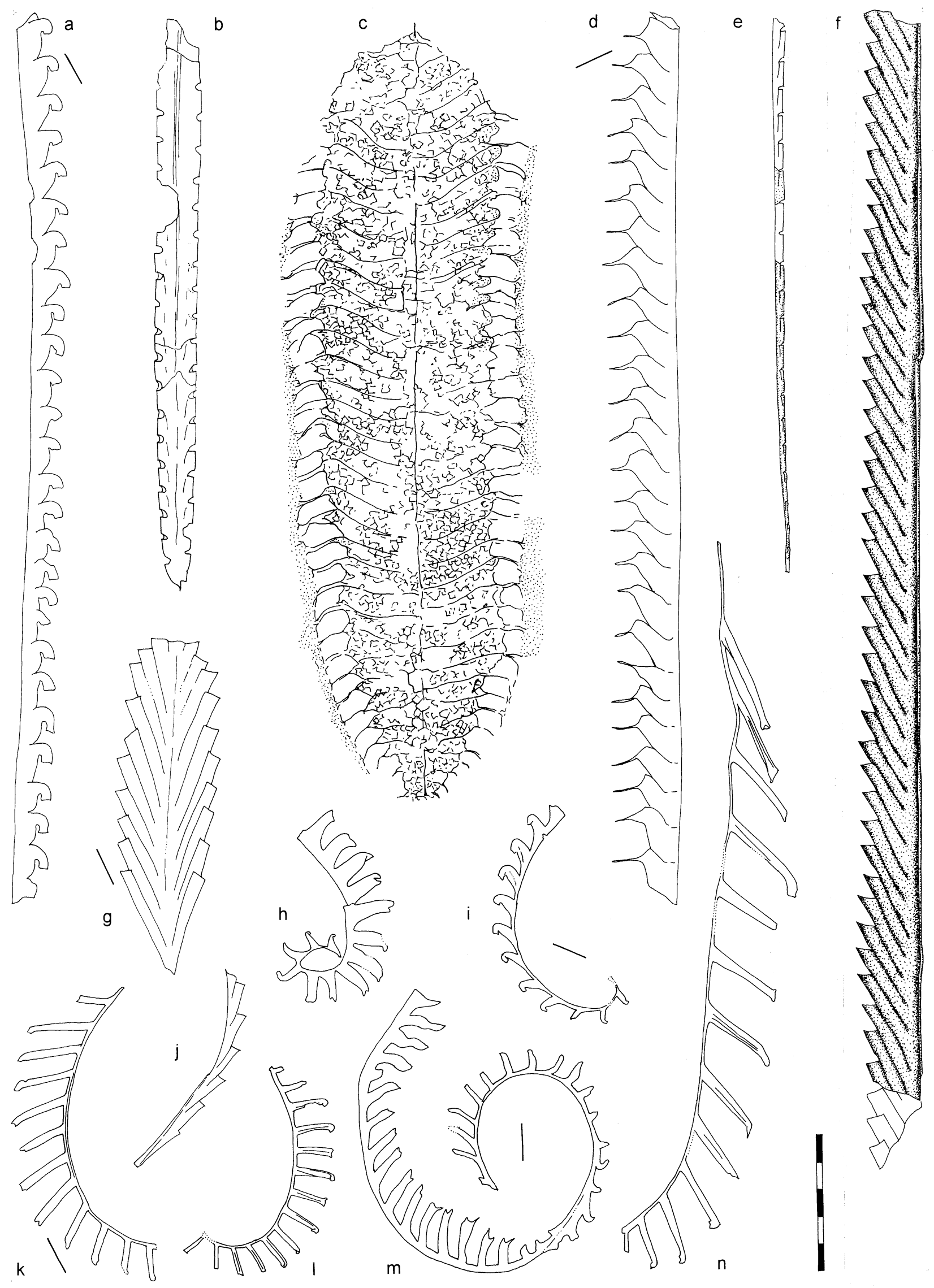

Figure 7. Graptolites from the ?acuminatus-cyphus, triangulatus, convolutus, linnaei and tullbergi biozones. (a) Monograptus lobiferus (McCoy), DPM 3402, convolutus Biozone, (b) Normalograptus normalis (Lapworth), DPM 3400, ?acuminatus-cyphus biozones, (c) Pseudoplegmatograptus sp.n., DPM 3428, upper linnaei Biozone (hispanicus Subzone), (d) Stimulograptus halli (Barrande), DPM 3431, hispanicus Subzone, (e) Monoclimacis griestoniensis (Nicol), DPM 3459, lower part of the tullbergi Biozone, 
rippled Los Puertos Quartzite. Black, micaceous silty shales are still intercalated with several thin beds of rippled quartzose siltstones. This lowermost part of the black shale sequence, $2.7 \mathrm{~m}$ thick, contains a rich, moderately diverse graptolite assemblage comprising: Rastrites linnaei Barrande - common in some beds, $R$. schaueri Storch \& Loydell - rare, Spirograptus guerichi Loydell, Storch \& Melchin, Torquigraptus planus (Barrande), 'Monograptus' gemmatus (Barrande), M. marri (Perner) - very rare, Paradiversograptus runcinatus (Lapworth), Pristiograptus variabilis (Perner), Parapetalolithus palmeus (Barrande) very rare, and Glyptograptus cf. supernus Fu. Rare Rastrites sp. cf. carnicus Seelmeier (sensu Storch \& Loydell, 1992), Monograptus cf. capillaris (Carruthers), and Parapetalolithus sp. are confined to the lower part of the subzone. Rastrites cf. fugax Barrande, Torquigraptus contortus (Perner), rare Streptograptus cf. johnsonae Loydell (?sp.n.), Pristiograptus renaudi Phillipot and Pseudoplegmatograptus sp.n. appear in the upper part of the subzone.

Although the composition of the assemblage is presumably influenced by the shallow water environment, the presence of some species ('M.' gemmatus, Paradiv. runcinatus, $P$. renaudi) and omission of some others, characteristic of the higher parts of the linnaei Biozone (Parapet. hispanicus, Stim. becki, P. bjerringus) allows correlation of the lowermost part of the section with the gemmatus and runcinatus subzones recognized by Loydell (1991) in Wales. In Bohemia the lowermost part of the linnaei Biozone is represented largely by barren mudstones. Stratigraphic ranges of some species (e.g. $M$. marri and $T$. proteus) differ from those recorded elsewhere. For instance, M. marri appears as high as in the utilis Subzone in Wales (Loydell, 1991) whilst the lowest records of the species came from the uppermost sedgwickii Zone of the Bohemian sections (Storch, 1994).

\section{6.d.2. Palmeus Subzone}

At the Checa section, the succeeding black micaceous shales, $0.3 \mathrm{~m}$ in thickness, yield a different graptolite assemblage, assigned here to the palmeus Subzone. It is composed of Rastrites linnaei Barrande, R. fugax Barrande, R. schaueri Storch \& Loydell, Spirograptus guerichi Loydell, Storch \& Melchin, Torquigraptus planus (Barrande), T. contortus (Perner), Stimulograptus halli (Barrande), Stim. becki (Barrande) - recorded in the upper part of the subzone, Monograptus marri Perner upper part of the subzone, Streptograptus plumosus (Baily) - lower part, Pristiograptus pristinus Pribyl,
$P$. renaudi Phillipot - lower part, $P$. variabilis (Perner), Pseudoplegmatograptus sp.n., Parapetalolithus palmeus (Barrande) - common (Figs 4, 8g), Parapet. elongatus (Boucek \& Pribyl) and Metaclimacograptus cf. asejradi Legrand - upper part.

We found an identical assemblage, characterized by R. fugax, Stim. halli, Stim. becki, Str. plumosus, M. marri, Parapet. palmeus and Parapet. elongatus, in the material from Central Spain (Almadén, Corral de Calatrava and Guadarrama areas), which is deposited in Madrid (Complutense University and Geominero Museum). This fauna corresponds with that of the palmeus Subzone of the Barrandian area in Bohemia (Storch, 1994).

\section{6.d.3. Hispanicus Subzone}

The upper part of the linnaei Biozone, represented by the hispanicus Subzone, is recorded widely in the Nevera and Tremedal massifs. At the Checa-Orea road cutting (loc. B) and at Orihuela del Tremedal (below the road at $\mathrm{km}$ 30.4 , loc. D, and road cutting at $\mathrm{km} \mathrm{37.0,} \mathrm{loc.} \mathrm{C),} \mathrm{the}$ black shale sequence of the Bádenas Formation begins with the hispanicus Subzone. The complete linnaei Biozone, embracing both the hispanicus and the underlying palmeus and runcinatus-gemmatus subzones, is developed only in the Checa section. The hispanicus Subzone is more than $4.5 \mathrm{~m}$ thick at Checa.

Thinly bedded black shales yielded a rich graptolite fauna composed of Rastrites linnaei (Barrande) - which in the upper part of the subzone becomes rare, $R$. schaueri Storch \& Loydell, R. abbreviatus Lapworth - rare, Spirograptus guerichi Loydell, Storch \& Melchin, Torquigraptus planus (Barrande), T. aff. proteus (Barrande) - in the upper part, rare, Stimulograptus halli (Barrande), Stim. becki (Barrande) - particularly common in the upper part, Stim. cf. utilis Loydell - in about the middle of the subzone, rare, Monograptus marri Perner, Streptograptus cf. storchi Loydell - in the upper part, rare, Str. sp. - rare, Str. filiformis Chen - restricted to thin level in the middle part, Str. cf. johnsonae Loydell (?sp.n.) - lower part, 'Paradiversograptus' aff. runcinatus (Lapworth) - middle part, rare, Pristiograptus pristinus Pribyl, $P$. bjerringus (Bjerreskov), Pseudoplegmatograptus sp.n., Parapetalolithus hispanicus (Haberfelner), Parapet. elongatus (Boucek \& Pribyl), Parapet. cf. altissimus (Elles \& Wood) - rare, and Metaclimacograptus cf. asejradi Legrand.

The same assemblage is known from Guadarrama region and from Almadén (Central Sierra Morena, province of Ciudad Real), the type locality of Parapet.

(f) Pristiograptus bjerringus (Bjerreskov), DPM 3439, hispanicus Subzone, (g) Petalolithus folium (Hisinger), DPM 3401, convolutus Biozone, (h) Demirastrites triangulatus (Harkness), DPM 3414, triangulatus Biozone, (i) 'Monograptus' denticulatus Törnquist, DPM 3405, convolutus Biozone, (j) Coronograptus gregarius (Lapworth), DPM 3415, triangulatus Biozone, (k) Rastrites peregrinus Barrande, DPM 3404, convolutus Biozone, (1) Rastrites approximatus Perner, DPM 3406, convolutus Biozone, (m) Demirastrites convolutus (Hisinger), DPM 3401, convolutus Biozone, (n) Rastrites schaueri Štorch \& Loydell, DPM 3432, hispanicus Subzone. (a, g, $\mathrm{i}, \mathrm{k}, \mathrm{l}, \mathrm{m}$ ) from Orihuela del Tremedal road cutting at km 30.5, (b) from Macizo del Tremedal, road cutting at km 31.1, (c-f, n) from Checa section, and $(h, j)$ from Checa-Orea road cutting. Each division of scale bar $=1 \mathrm{~mm}$. 
J. C. GUTIÉRREZ-MARCO \& P. STORCH

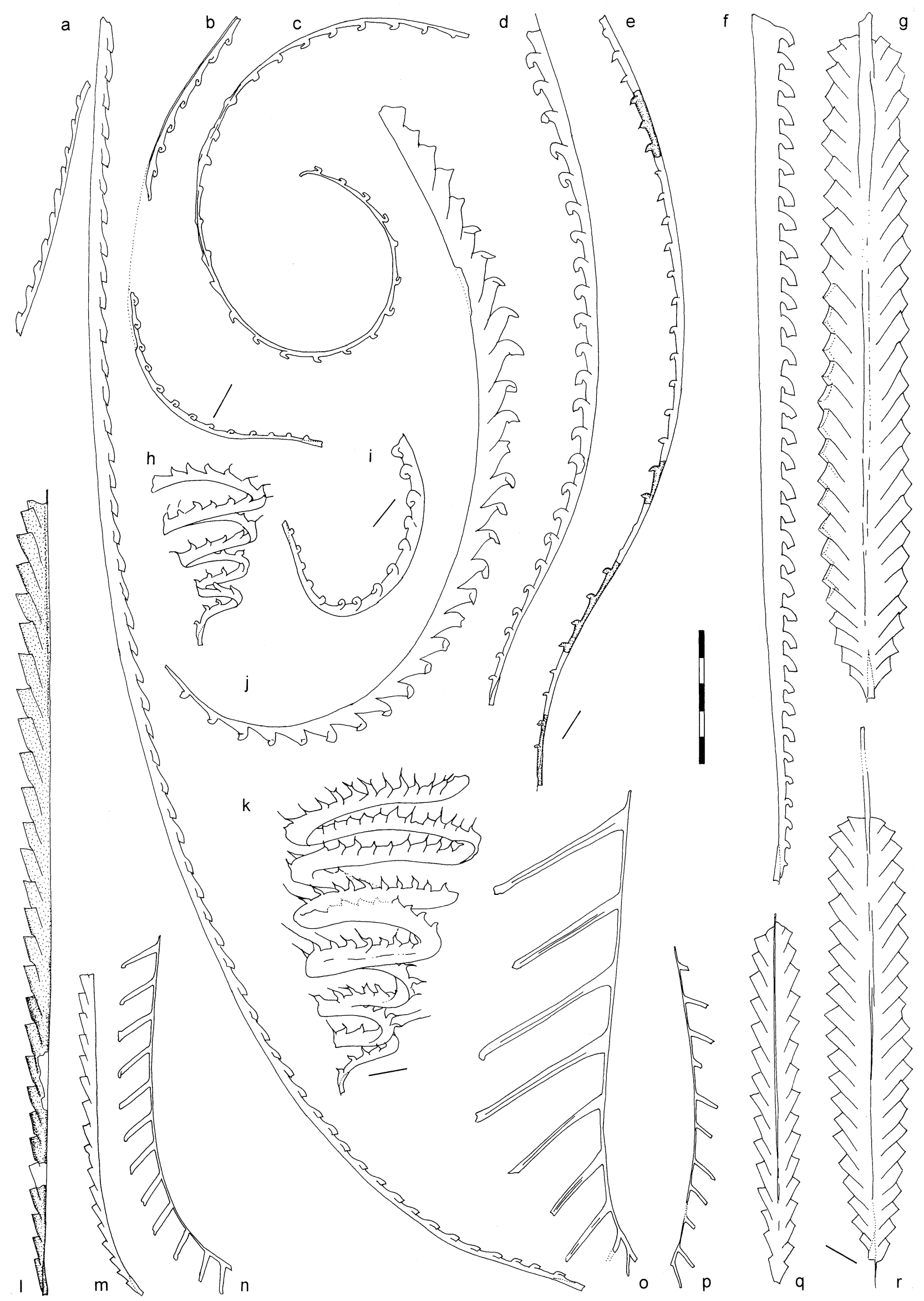

Figure 8. For legend see facing page. 
hispanicus (Haberfelner, 1931). The presence of Str. filiformis and Stim. cf. utilis, the appearance of P. bjerringus and Str. cf. storchi, and last occurrences of R. linnaei, S. guerichi and Stim. halli, allow correlation of our hispanicus Subzone with the utilis Subzone recognized in mid-Wales (Loydell, 1991). The assemblage still belongs to the pre-extinction fauna of the utilis Subzone, discussed by Loydell (1994), which there and elsewhere is succeeded by a low-diversity post-extinction fauna of the turriculatus Biozone. The assemblage of the Spanish hispanicus Subzone corresponds well, except in having more common and diverse streptograptids, with that of the hispanicus Subzone of Bohemia (Storch, 1994).

\section{6.e. Turriculatus Biozone}

The base of the biozone is marked by the appearance of the index graptolite Spirograptus turriculatus which replaces its ancestor $S$. guerichi, one of the age-diagnostic graptolites of the preceding biozone. We recorded the turriculatus Biozone at Checa section (loc. A), at the ChecaOrea road cutting (loc. B), and along the Orihuela del Tremedal road cutting on $\mathrm{km} 37.1$ (loc. C). The Checa section, the best of the three sections examined, exhibits the lower and middle parts of the zone ( $4.6 \mathrm{~m}$ thick). The upper part of the turriculatus Biozone has not been exposed in 1992-1995.

Sandy-micaceous laminites yield abundant, although low diversity and often poorly preserved faunas, in the lower part dominated by Stimulograptus becki. The assemblage consists of Spirograptus turriculatus (Barrande), Torquigraptus proteus (Barrande) - in the upper part of the available section, T. planus (Barrande) lower part, Stimulograptus becki (Barrande) - very common in the lower part of the section, Monograptus marri Perner, Pristiograptus bjerringus (Bjerreskov), Parapetalolithus tenuis (Barrande), Parapet. sp. aff. schaueri (Loydell), and Metaclimacograptus cf. asejradi Legrand.

The low-diversity assemblage belongs to the postextinction turriculatus Biozone fauna in the sense of Loydell (1994). It is assigned to the lower part of the biozone because of the presence of $T$. planus. $T$. proteus appears well above the base of the biozone. The faunal composition, however, is rather different from that described by Loydell (1991) from Wales. It resembles more that of the lower part of the turriculatus Biozone of the Barrandian area (Bohemia) listed by Storch (1994).

The turriculatus Biozone has been widely recognized in the Hesperian Massif, although in many cases it included the underlying linnaei Biozone, unrecognized by many previous authors who did not distinguish $S$. turriculatus (Barrande) from its ancestor S. guerichi (Loydell, Melchin \& Storch).

\section{6.f. ?Crispus Biozone}

Clayey black shales assigned with question to the crispus Biozone have been recorded at only one section, the Orihuela del Tremedal road-cutting at km 37.1 (loc. C). The shales are more than $5 \mathrm{~m}$ thick. Several fragmentary rhabdosomes of 'Monograptus' crispus (Lapworth)? were found along with Torquigraptus cf. arcuatus (Boucek), T. proteus (Barrande)?, Cochlograptus veles (Richter), Streptograptus exiguus (Lapworth) rare, Pseudoplegmatograptus obesus (Lapworth), Parapetalolithus cf. schaueri (Loydell) - ?sp.n. and Paraclimacograptus? flamandi (Legrand).

The assemblage is easily distinguished from those of the adjoining turriculatus and griestoniensis biozones. The presence of $C$. veles, $T$. cf. arcuatus, and Str. exiguus, which accompany the specimens assigned to ' $M$.' crispus?, enables the crispus Biozone to be identified tentatively from the Western Iberian Cordillera for the first time.

\section{6.g. Griestoniensis Biozone}

The griestoniensis Biozone has been recognized from the Checa section (loc. A), the Orihuela del Tremedal road cutting (km 37.1, loc. C) and El Pobo de Dueñas (loc. F, Sierra Menera Massif). At the last locality the black-shale sequence overlying the Los Puertos Quartzite begins at the griestoniensis Biozone. At Checa the base of the zone, which has a thickness here of over $5 \mathrm{~m}$, has not been exposed.

The clayey shales of the griestoniensis Biozone are dominated by Torquigraptus aff. spiraloides (Pribyl) -

Figure 8. Graptolites from the linnaei and turriculatus biozones. (a) Paradiversograptus runcinatus (Lapworth), DPM 3455, lower linnaei Biozone (runcinatus-gemmatus Subzone), (b) Streptograptus sp. cf. johnsonae Loydell, DPM 3438, upper linnaei Biozone (lower part of the hispanicus Subzone), (c) 'Monograptus' gemmatus (Barrande), DPM 3444, runcinatus-gemmatus Subzone, (d) Stimulograptus cf. utilis Loydell, DPM 3440, hispanicus Subzone, (e) Stimulograptus becki (Barrande), DPM 3434 - uppermost part of the hispanicus Subzone, (f) Monograptus marri Perner, DPM 3429, hispanicus Subzone, (g) Parapetalolithus palmeus (Barrande), DPM 3452, middle part of the linnaei Biozone (palmeus Subzone), (h) Spirograptus guerichi Loydell, Storch \& Melchin, DPM 3435, hispanicus Subzone, (i) Streptograptus plumosus (Baily), DPM 3450, palmeus Subzone, (j) Torquigraptus planus (Barrande), DPM 3454, palmeus Subzone, (k) Spirograptus turriculatus (Barrande), DPM 3445, lower part of the turriculatus Biozone, (l) Pristiograptus pristinus Pribyl, DPM 3436, hispanicus Subzone, (m) Pristiograptus renaudi Philippot, DPM 3443, lower part of the palmeus Subzone, (n) Rastrites cf. fugax Barrande, DPM 3442, upper part of the runcinatus-gemmatus Subzone, (o) Rastrites linnaei Barrande, DPM 3456, hispanicus Subzone, (p) Rastrites fugax Barrande, DPM 3453, palmeus Subzone, (q) Parapetalolithus elongatus (Boucek \& Pribyl), DPM 3451, palmeus Subzone, (r) Parapetalolithus hispanicus (Haberfelner), DPM 3457, hispanicus Subzone. All from the Checa section. Each division of scale bar $=1 \mathrm{~mm}$. 


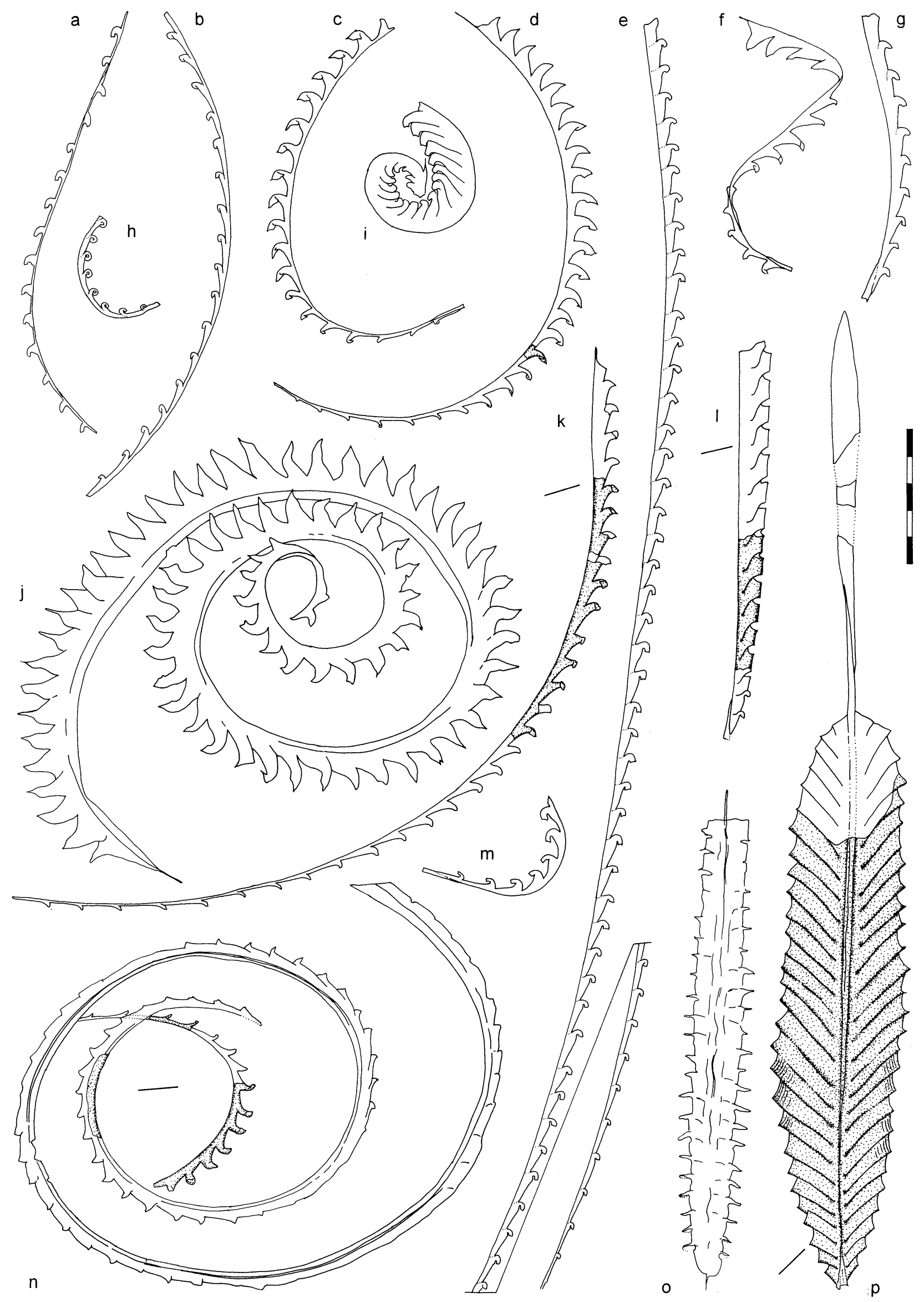

Figure 9. For legend see facing page. 
?sp.n., Parapetalolithus cf. schaueri (Loydell) - ?sp.n. and Paraclimacograptus? flamandi (Legrand), with subordinate Monoclimacis griestoniensis (Nicol), Monograptus priodon (Bronn), Retiolites geinitzianus (Barrande), and rare Cochlograptus veles (Richter). Monograptus sp.n. A appears in the upper part of the griestoniensis Biozone, in which common $M$. drepanoformis Toghill \& Strachan and Streptograptus aff. sartorius (Törnquist) have also been recorded.

The presence of Mcl. griestoniensis and $M$. drepanoformis enables correlation with the griestoniensis Biozone of Scotland (Toghill \& Strachan, 1970), Armorican Massif in France (Paris, Rickards \& Skevington, 1980) and Bornholm (Bjerreskov, 1975).

\section{6.h. Tullbergi Biozone}

An easily recognized tullbergi Biozone has been studied above the griestoniensis Biozone at El Pobo de Dueñas (loc. F) and Checa (loc. A). It is represented by a sequence of clayey shales more than $16 \mathrm{~m}$ thick $(16.3 \mathrm{~m}$ at Checa) with common graptolites, in some beds pyritized and preserved in relief. A non-graptolite fauna of minute orthid brachiopods and fragmentary eurypterids and peltocarids is present in some beds.

The graptolite assemblage is dominated by Torquigraptus cf. tullbergi (Boucek) - ?sp.n., T. tullbergi (Boucek) and Monograptus sp.n. A, accompanied by Monoclimacis griestoniensis (Nicol) - lower part of the biozone, $M c l$. crenulata (Elles \& Wood) - rare, confined to two thin levels, Cochlograptus veles (Richter) - very rare, Monograptus priodon (Bronn), M. sp.n. B, in the upper part, Retiolites geinitzianus (Barrande), Pseudoplegmatograptus ex gr. obesus (Lapworth) and Paraclimacograptus? flamandi (Legrand) - lower part.

The low diversity graptolite fauna of the tullbergi Biozone of the Western Iberian Cordillera is very unusual, being dominated by species which are uncommon or absent elsewhere. We chose the same index graptolite for this level as did Storch (1994) in Bohemia. In both regions T. tullbergi appears to be confined to its own biozone. The true T. tullbergi (Boucek) differs in its rapidly expanding rhabdosome from the closely related $T$. cf. tullbergi (?sp.n.) which also has its acme in the same biozone (Fig. 9c, d). T. aff. spiraloides (?sp.n.) from the griestoniensis Biozone can be distinguished from the latter two species after its regularly spiral rhabdosome with less isolated metathecae and more robust prothecae. Mcl. crenulata is rare in the Western Iberian Cordillera and is unknown from other Spanish Llandovery sequences. Several specimens of Mcl. crenulata, found in approximately the middle part of the tullbergi Biozone at the Checa section, provide a much improved basis for the broad, international correlation of the tullbergi Biozone.

\section{6.i. Spiralis Biozone}

The highest part of the Llandovery, exposed in the sections at Checa (loc. A) and El Pobo de Dueñas (loc. B), is formed of black shales (thin-bedded mudstones), at the latter locality with muddy limestone nodules. The shales, more than $15 \mathrm{~m}$ in thickness (13 m exposed at Checa), yield low diversity faunas of common graptolites of the spiralis Biozone. The non-graptolite fauna is represented by eurypterids and orthoconic nautiloids. Weathered limestone nodules found at El Pobo de Dueñas yield bivalves, orthoceratids, eurypterids and phyllocarids. The abundance of decalcified nodules at this locality was known as early as the eighteenth century (Torrubia, 1754, pl. 12, figs 2 left and 2 right). The nodules are also known from other localities in the Tremedal and Sierra Carbonera massifs.

The graptolite assemblage is composed of Oktavites spiralis (Geinitz) - common in some beds, Torquigraptus flagellaris (Törnquist), Streptograptus cf. anguinus Pribyl - rare in the upper part, Str. aff. extenuatus Boucek \& Pribyl - rare, Diversograptus ramosus Manck - in the uppermost part of the sequence, Monoclimacis? sp. uncommon, Monograptus priodon (Bronn), M. sp.n. B, and Retiolites geinitzianus (Barrande).

The occurrence of Str. cf. anguinus, D. ramosus and T. flagellaris suggests that only the lower and, at most, middle part of the spiralis Biozone are preserved in the present sections. T. flagellaris was described by Törnquist (1892) from the spiralis Biozone of southern Sweden. In Bohemia, Pribyl (1945) and Boucek (1953) reported M. curvus Manck from the crenulata-spiralis boundary beds. At least some of their material, however, belongs to T. flagellaris.

\section{Palaeontological notes}

Metaclimacograptus cf. asejradi Legrand (Fig. 10e, f) can be distinguished from other metaclimacograptids in

Figure 9. Graptolites from the crispus, griestoniensis, tullbergi and spiralis biozones. (a) Streptograptus aff. sartorius (Törnquist), DPM 3425, griestoniensis Biozone, (b) Diversograptus ramosus Manck, DPM 3461, spiralis Biozone, (c) Torquigraptus tullbergi (Boucek), DPM 3411, tullbergi Biozone, (d) Torquigraptus cf. tullbergi (Boucek) - ?sp.n., DPM 3408, tullbergi Biozone, (e) Monograptus sp.n. A, DPM 3462, tullbergi Biozone, (f) Torquigraptus flagellaris (Törnquist), DPM 3407, spiralis Biozone (g) Monograptus sp.n. B, DPM 3409, spiralis Zone, (h) Streptograptus exiguus (Lapworth), DPM 3418, crispus Biozone, (i) Cochlograptus veles (Richter), DPM 3417, crispus Biozone, (j) Oktavites spiralis (Geinitz), DPM 3423, spiralis Biozone, (k) Torquigraptus cf. arcuatus (Boucek), DPM 3416, crispus Biozone, (1) Monoclimacis crenulata (Elles \& Wood), DPM 3447, tullbergi Biozone, (m) Monograptus drepanoformis Toghill \& Strachan, DPM 3427, griestoniensis Biozone, (n) Torquigraptus aff. spiraloides (Pribyl) - ?sp.n., DPM 3412, griestoniensis Biozone, (o) Paraclimacograptus? flamandi (Legrand), DPM 3421, lower part of the tullbergi Biozone, (p) Parapetalolithus cf. schaueri (Loydell) ?sp.n., DPM 3413, griestoniensis Biozone. (a, b, d, e, j, l-p) from the Checa Section, (c, f, g) from El Pobo de Dueñas, (h, i, k) from the Orihuela del Tremedal road cutting at $\mathrm{km} 37.1$. Each division of scale bar $=1 \mathrm{~mm}$. 

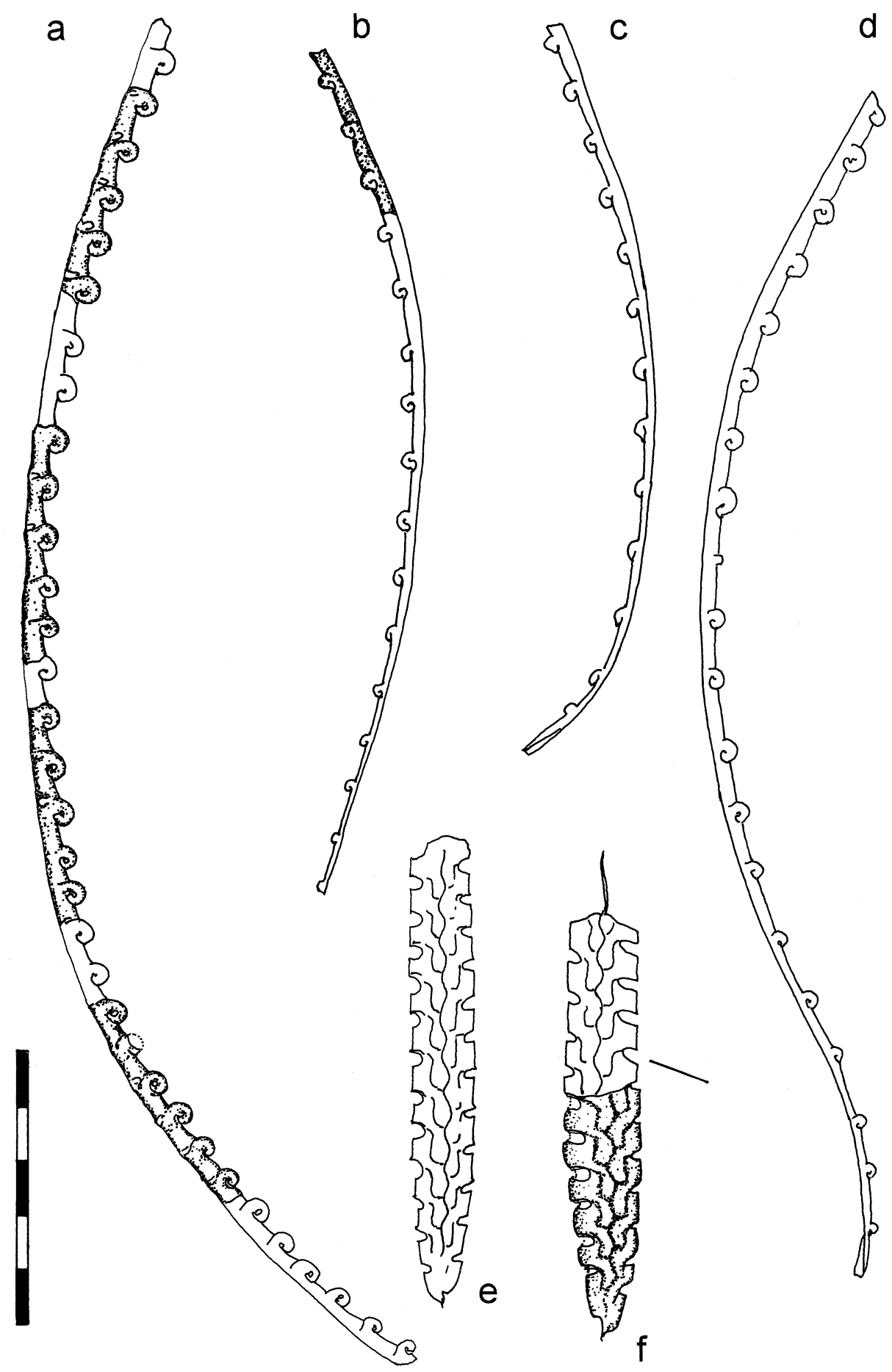

Figure 10. Graptolites from the linnaei and spiralis biozones. (a, b, d) 'Paradiversograptus' aff. runcinatus (Lapworth); (a, b) DPM 3480, (d) DPM 3481, hispanicus Subzone of the linnaei Biozone; (c) Streptograptus cf. anguinus Pribyl, DPM 3484 - lower part of the spiralis Biozone; (e, f) Metaclimacograptus cf. asejradi Legrand, (e) DPM 3441, (f) DPM 3485, hispanicus Subzone of the linnaei Biozone. All specimens from the Checa Section. Each division of scale bar $=1 \mathrm{~mm}$.

having a larger rhabdosome and a moderately undulating median septum. The rhabdosome is $10-12 \mathrm{~mm}$ long, $0.8 \mathrm{~mm}$ wide at the level of the th $1^{1}-1^{2}$ apertures and 1.3-1.4 mm wide in the distal portion (up to $1.5 \mathrm{~mm}$ when flattened). The thecae number $c .15$ in $10 \mathrm{~mm}$ (the two thecae repeat distance is $1.4 \mathrm{~mm}$ at the level of th2, distal two thecae repeat distance is $c .1 .6 \mathrm{~mm}$ ). Thecae are doubly sigmoidally curved with almost straight supragenicular walls. Metacl. asejradi as described by Legrand (1993) differs from the present material only in its lesser distal width (1.1-1.3 mm).

Parapetalolithus cf. schaueri (?sp.n.) a species widespread over the whole Iberian Peninsula, is a very large parapetalolithid with a prominent nematularium (Fig. $9 \mathrm{p})$. The rhabdosome widens from $1.3-1.5 \mathrm{~mm}$ at the level of the first thecal pair to $4.4-4.8 \mathrm{~mm}$ at the level of 
the tenth thecal pair. The maximum width of $4.8-5.4 \mathrm{~mm}$ is attained with about the fifteenth thecal pair. The sicula is $1.9 \mathrm{~mm}$ long, its apex reaches to about the base of th $3^{2}$. Tubular distal thecae with everted apertures attain $3 \mathrm{~mm}$ in length and overlap for four-fifths to five-sixths of their length. Robust proximal portions of the present rhabdosomes appear to be even wider, and more rapidly widening than those of Parapet. schaueri (Loydell). The material of Parapet. schaueri collected by Schauer (1971, described as Petalolithus palmeus posterus) and Loydell (1992) has probably never reached the maturity and size common in Parapet. cf. schaueri (?sp.n.). In our previous lists of the Upper Llandovery graptolite faunas of the Iberian Peninsula, the specimens of Parapet. cf. schaueri (?sp.n.) were referred to Petalograptus giganteus Boucek \& Pribyl. Recently we examined the extremely tectonically broadened type material of Pet. giganteus and concluded that the species should be regarded as a junior synonym of Parapet. hispanicus (Haberfelner) or Parapet. conicus (Boucek).

Several specimens assigned to Parapetalolithus sp. aff. schaueri resemble the species described above in having rapidly widening rhabdosomes. They differ from Parapet. cf. schaueri in having a less robust proximal end and a lesser dorso-ventral width of the rhabdosome. They may also resemble Parapetalolithus hispanicus (Haberfelner).

Pseudoplegmatograptus sp.n. (Fig. 7c) is a large pseudoplegmatograptid with well-developed external membranous appendages forming an external cover to the rhabdosome. The membrane appendages grow out from spathes (for explanation, see Bates \& Kirk, 1992) - ramified distal portions of paired apertural spines. The rhabdosome rapidly expands to its maximum width of $6.8-8.0 \mathrm{~mm}$ which is attained at about the tenth thecal pair. The rhabdosome is $9.0-10.0 \mathrm{~mm}$ wide including the apertural spines and external membrane. The meshwork of lists appears irregular. Septal bars (for explanation see Loydell, Storch \& Bates, in press) are inclined at an angle of $60-65^{\circ}$ to the rhabdosome axis. The two thecae repeat distance (2TRD) is $2.0-2.2 \mathrm{~mm}$. The present species differs from Pseudoplegm. obesus (Lapworth) in having a wider and longer rhabdosome, with less closely packed thecae and well-developed spathes bearing external membranous appendages.

Monograptus sp.n. A (Fig. 9e) is a long, slowly expanding monograptid with gentle, persistent dorsal curvature, and almost isolated, simply hooked thecae. The sicula has not been found. The initial portion of the rhabdosome is $0.35 \mathrm{~mm}$ wide, thereafter the dorsoventral width increases to about $1.0 \mathrm{~mm}$ within a distance of more than $60 \mathrm{~mm}$. The maximum length exceeds $250 \mathrm{~mm}$. The thecae are low-triangulate, the ventral prothecal walls being inclined at an angle of $10^{\circ}$ in the proximal thecae and at $20-25^{\circ}$ in the distal thecae. Metathecae are simply hooked with proximo-ventrally to proximally facing apertures. The 2TRD (two thecae repeat distance) is $c .2 .6 \mathrm{~mm}$ proximally and $1.7-2.0 \mathrm{~mm}$ distally.
Monograptus sp.n. B (Fig. 9g) is a slender, gradually expanding monograptid with a dorsally curved proximal part and straight distal part. The apex of the $1.8-1.9 \mathrm{~mm}$ long sicula reaches up to about half up th2. The thecal height increases gradually from $0.7-0.8 \mathrm{~mm}$, at the level of th1, to $c .1 .6 \mathrm{~mm}$ about $30 \mathrm{~mm}$ from the proximal end. The 2TRD of c. $2.0 \mathrm{~mm}$ is maintained throughout the rhabdosome. Monograptus sp.n. B differs from monograptids of the priodon group (including Monograptus parapriodon Boucek) in having less overlapping thecae and shorter metathecal hooks, formed of a dorsal wall of the metatheca.

Several poorly preserved specimens from the lower part of the runcinatus-gemmatus Subzone are characterized by a slender, dorsally curved rhabdosome (maximum width of $0.45 \mathrm{~mm}$ ) and widely spaced thecae (distal 2TRD is $2.7-3.2 \mathrm{~mm}$ ) with small, possibly hooked metathecae and almost parallel-sided prothecae. They are here tentatively assigned to Monograptus cf. capillaris Carruthers sensu Loydell (1993). The proximal end of this form has not yet been recorded.

Storch \& Loydell (1992) discussed a considerable variability in rastritid rhabdosomes as regards thecal length and spacing. The present material assigned to Rastrites cf. fugax Barrande came from rather homogeneous populations characterized by dorsally curved rhabdosomes with $1.5-1.7 \mathrm{~mm}$ long, proximally directed metathecae (thecal inclination $125-135^{\circ}$ ) and well-developed apertural hooks. A dorsally curved rhabdosome and slightly longer, more inclined thecae with pronounced apertural hooks distinguish the present specimens (Fig. 8n) from the typical $R$. fugax. In the light of intraspecific variability of rastritids, however, the present material is not sufficient for any reliable taxonomic conclusions.

Streptograptus cf. johnsonae (?sp.n.) (Fig. 8b) is closest in form and dimensions to Str. johnsonae Loydell. It is, however, wider throughout the length of its rhabdosome, the dorso-ventral width of which expands from $0.3 \mathrm{~mm}$ (at the level of th1) and $0.4 \mathrm{~mm}$ at the level of th10 to $0.6-0.65 \mathrm{~mm}$ distally. The thecae of Str. johnsonae are of identical shape but slightly more closely spaced than those of Str. cf. johnsonae in which the two thecae repeat distance is initially $1.55 \mathrm{~mm}$ and gradually attains $1.9 \mathrm{~mm}$ in the distal part of the rhabdosome. The present material occurs at a lower stratigraphic level than the material of Loydell (1991). Another similar species Str. petilus Hutt - is still more slender and has more closely packed thecae.

The material assigned tentatively to Streptograptus cf. anguinus Pribyl (Fig. 10c) compares well with the topotype Bohemian specimens, the only observed difference being a less ventrally curved proximal portion of the rhabdosome. In this feature, it resembles more the proximal portion of the slightly more gracile Str. extenuatus Boucek \& Pribyl.

Several straight, rather robust streptograptid fragments with two thecae repeat distance of $c .2 .0 \mathrm{~mm}$ were tentatively assigned to Streptograptus cf. storchi Loydell. 
Streptograptus aff. sartorius (Fig. 9a) of this paper is a slender species with thread-like, parallel-sided prothecae and isolated, probably hooked rather than coiled metathecae. The 2TRD is $2.5-2.7 \mathrm{~mm}$, and the height of the metathecae varies between $0.45-0.6 \mathrm{~mm}$. We provisionally assigned our specimens to Streptograptus, although the poor preservation of the present material left the thecal details obscure. The specimens which originate from the upper griestoniensis Biozone of Checa and El Pobo sections (Fig. 3, locs A, F) differ from both Str. sartorius (Törnquist) and Str. aff. sartorius sensu Zalasiewicz (1994) in having more widely spaced thecae.

Specimens assigned to 'Paradiversograptus' aff. runcinatus (Lapworth) have a rhabdosome which is gently dorsally curved proximally and thereafter ventrally curved (Fig. 10a, b, d). The dorso-ventral width of the rhabdosome gradually increases from $0.3 \mathrm{~mm}$ to at least $0.7 \mathrm{~mm}$ distally. The 2TRD is $1.8-1.9 \mathrm{~mm}$. Both the rhabdosome form and dimensions are similar to those of Paradiv. runcinatus (Lapworth). The thecae, however, are streptograptid - typically incurved, retroverted rather then hooked. Streptograptus pseudoruncinatus (Bjerreskov) has more densely spaced thecae and a less curved rhabdosome.

Torquigraptus cf. arcuatus (Fig. 9k) differs from the type and topotypic material of T. arcuatus (Boucek) in having a gently dorsally curved rhabdosome with a more elongated, gradually expanding proximal portion. In $T$. cf. arcuatus the proximal part is gracile, c. $0.2 \mathrm{~mm}$ wide, and the maximum dorso-ventral width of the rhabdosome $1.0-1.1 \mathrm{~mm}$ - is attained at about the twenty-fifth theca. The 2TRD measures $3 \mathrm{~mm}$ near the proximal end of the rhabdosome, then gradually decreases to $2.6 \mathrm{~mm}$ at the level of th10, and 1.9-2.2 $\mathrm{mm}$ in the most distal thecae. In the topotypic material of T. arcuatus the 2TRD of $1.9-2.2 \mathrm{~mm}$ is almost uniform throughout the rhabdosome. Apart from the more elongated prothecae in the Spanish specimens the two forms possess the same, isolated metathecae with simple, laterally twisted apertures.

Torquigraptus aff. spiraloides (?sp.n.) resembles T. spiraloides (Pribyl) in its spiraliform rhabdosome and laterally twisted torquigraptid thecae. It differs from the latter species, however, in having a more elongated proximal part and in the lesser maximum width of the rhabdosome. In the common mode of preservation (see Fig. 9n) the distal metathecae of $T$. aff. spiraloides (?sp.n.) are perpendicular or almost perpendicular to the plane of the rhabdosome spiral. The regularly spiral rhabdosome with more robust prothecae and less isolated metathecae, oriented perpendicularly to the plane of the rhabdosome spiral, distinguish $T$. aff. spiraloides (?sp.n.) also from T. tullbergi (Boucek) and $T$. cf. tullbergi (?sp.n.). The latter species differs also in having a gracile, more elongated proximal portion of the rhabdosome. T. aff. spiraloides (?sp.n.) is a common and widespread member of the Mcl. griestoniensis Biozone assemblage. From Bohemia, however, the identical form was reported as Monograptus cf. contortus Perner by Storch (1994); in Wales the equivalent form was referred to T. tullbergi cf. spiraloides by Zalasiewicz (1994).
Material tentatively assigned to Torquigraptus cf. tullbergi (?sp.n.) (Fig. 9d) contains a gracile, very elongated proximal portion of the rhabdosome. The rhabdosome expands from an initial width of $0.2 \mathrm{~mm}$ (height of th1) to c. $1.3 \mathrm{~mm}$ at the level of the sixteenth theca. The 2TRD 2 is c. $2.5 \mathrm{~mm}$, then decreases to about $1.9 \mathrm{~mm}$ in the mesial part of the rhabdosome and increases again in its most distal portion. Several centimetres from the proximal end, the 2TRD reaches $2.7 \mathrm{~mm}$. The particularly long and gracile proximal part of the rhabdosome (see also specimens figured by Schauer 1971, pl. 29, fig. 17, and Zalasiewicz, 1994, text-fig. 8F) lead us to separate provisionally $T$. cf. tullbergi (?sp.n.) from the coeval T. tullbergi (Boucek). We are aware of considerable variability in proximal elongation and expansion of the torquigraptid rhabdosomes. Further material has to be studied before the new species is formally established.

Acknowledgements. We are grateful to Drs P. Herranz (CSIC, Madrid) and D. K. Loydell (University of Portsmouth) for a critical reading of the earlier versions of the manuscript. D. K. Loydell kindly improved the English, $\mathrm{Dr}$ M. Oczlon (Heidelberg) loaned some graptolites collected by the late Prof. L. Greiling, and Prof. A. R. Fortuin (University of Amsterdam) provided a copy of an unpublished map of the Nevera Massif. Dr J. Zalasiewicz (University of Leicester) and one anonymous referee are thanked for helpful reviews. Our work was carried out within the framework of the Project PB96-0839 of the Spanish Dirección General de Enseñanza Superior (Ministerio de Educación y Cultura) operated by JCG-M. P. Storch also acknowledges the financial support provided by the Grant Agency of the Academy of Sciences of the Czech Republic (Grant A3013503).

\section{References}

Bargalló, M. 1928. Graptolites de Sierra Menera. Boletín de la Real Sociedad Española de Historia Natural 28(5), 258.

Bascones Alvira, L., Martín Herrero, D. \& La Moneda, E. 1982. Memoria explicativa de la Hoja no 515 (El Pobo de Dueñas) del Mapa Geológico de España a escala 1:50000 (Segunda Serie). Instituto Geológico y Minero de España, $59 \mathrm{pp}$.

BAtES, D. E. B. \& KIRK, N. H. 1992. The ultrastructure, mode of construction and functioning of a number of Llandovery ancorate diplograptid and retiolitid graptolites. Modern Geology 17(1-3), 1-270.

BERRY, W. B. N. \& BouCOT, A. J. 1972. Silurian graptolite depth zonation. International geological Congress, 24th session, section 7, Paleontology, pp. 59-65. Montreal.

BJERRESKOV, M. 1975. Llandoverian and Wenlockian graptolites from Bornholm. Fossils and Strata 8, 1-94.

BJERRESKOV, M. 1986. Ordovicium-Silur graensen pa Bornholm. Dansk geologiske Foreningens., Arsskrift (1985), 15-18.

Boucek, B. 1953. Biostratigraphy, Development and Correlation of the Zelkovice and Motol Beds of the Silurian of Bohemia. Sborník Ústredního ústavu geologického, Oddíl paleontologický 20, 421-84 (in Czech, English summary).

Boucot, A. J. 1975. Evolution and Extinction Rate Controls. Amsterdam: Elsevier, $426 \mathrm{pp}$.

Brenchley, P. J., Romano, M. \& Gutiérrez-Marco, J. C. 1986. Proximal and distal hummocky cross-stratified 
facies on a wide Ordovician shelf in Iberia. In Shelf Sands and Sandstones (eds R. J. Knight and J. R. McLean), pp. 241-55. Canadian Society of Petroleum Geologists, Memoir no. 2.

Brenchley, P. J., Romano, M., Young, T. P. \& Štorch, P. 1991. Hirnantian glaciomarine diamictites - evidence for the spread of glaciation and its effect on Upper Ordovician faunas. In Advances in Ordovician Geology (eds C. R. Barnes and S. H. Williams), pp. 325-36. Geological Survey of Canada, Paper 90-9.

Brett, C. E., Boucot, A. J. \& Jones, B. 1993. Absolute depths of Silurian benthic assemblages. Lethaia 26, 25-40.

Calvo, L. 1895. Geología de los alrededores de Albarracín (Teruel). Boletín de la Comisión del Mapa Geológico de España 20 (for 1893), 319-48.

CApote, R. \& GonZÁlez Lodeiro, F. 1983. La estructura herciniana en los afloramientos paleozoicos de la Cordillera Ibérica. In Libro Jubilar J.M. Ríos. Geología de España, Tomo 1 (ed. J. A. Comba), pp. 513-29. Instituto Geológico y Minero de España, 656 pp.

CARLs, P. 1974. Die Proschizoporiinae (Brachiopoda, Silurium-Devon) der Östlichen Iberischen Ketten (Spanien). Senckenbergiana lethaea 55, 153-227.

CARLS, P. \& GandL, J. 1967. The Lower Devonian of the Eastern Iberian Chains (NE Spain) and the distribution of its Spiriferacea, Acastavinae and Asteropyginae. In International Symposium on the Devonian System, Calgary (ed. D. H. Oswald), pp. 453-64. Alberta Society of Petroleum Geology no. 2.

CAstel, C. 1881. Descripción física, geognóstica, agrícola y forestal de la provincia de Guadalajara. Boletín de la Comisión del Mapa Geológico de España 8, 158-264.

CHEN, X. 1990. Graptolite depth zonation. Acta Palaeontologica Sinica 29, 507-26.

COOPER, R. A., ForTEY, R. A. \& LiNDHOLM, K. 1991. Latitudinal and depth zonation of early Ordovician graptolites. Lethaia 24, 199-218.

CORTÁZAR, D. 1885. Bosquejo físico-geológico y minero de la provincia de Teruel. Boletín de la Comisión del mapa Geológico de España 12, 263-607.

Dereims, A. 1898. Recherches géologiques dans le sud de l'Aragón. Thése Doctorale. Annales Hébert, Lille, 2, 199 pp.

Fortuin, A. R. 1984. Late Ordovician glaciomarine deposits (Orea Shale) in the Sierra de Albarracín, Spain. Palaeogeography, Palaeoclimatology, Palaeoecology 48, 245-61.

GANDL, J. 1972. Die Acastavinae und Asteropyginae (Trilobita) Keltiberiens (NE-Spanien). Abhandlungen der Senckenbergischen Naturforschenden Gesellschaft 530, $1-184$.

Grahn, Y. \& PARIS, F. 1992. Age and correlation of the Trombetas Group, Amazonas Basin, Brazil. Revue de Micropaléontologie 35, 197-209.

Haberfelner, E. 1931. Eine Revision der Graptolithen der Sierra Morena (Spanien). Abhandlungen der Senckenbergischen Naturforschenden Gesellschaft 43, 19-66.

HAVlíceK, V. \& ŠTORCH, P. 1990. Silurian brachiopods and benthic communities in the Prague Basin (Czechoslovakia). Rozpravy Ústredního ústavu geologického 48, 1-275.

HERNÁNDEZ SAMPElAYo, P. 1969. Graptolítidos españoles. Recopilados por Rafael Fernández-Rubio. Notas y Comunicaciones del Instituto Geológico y Minero de España 57, 3-77.

Herranz Araúso, P. 1968. Nota preliminar sobre el estudio geológico del Norte de Sierra Menera (Cordillera Ibérica). Acta Geológica Hispánica 3(3), 49-53.

JAEGER, H. 1976. Das Silur und Unterdevon vom thuringischen Typ in Sardinien und seine regionalgeologische Bedeutung. Nova Acta Leopoldina 45(224), 263-99.

JORDANA Y SOLER, L. 1935. Breve reseña físico-geológica de la provincia de Guadalajara. Boletín del Instituto geológico y Minero de España 54, 197-215.

Kindelán, V. \& RANZ, M. 1918. Criaderos de Hierro de España. Tomo 3. Criaderos de Guadalajara y Teruel. Memorias del Instituto Geológico de España 29, 1-230.

Koren', T. N., Lenz, A. C., Loydell, D. K., Melchin, M. J., ŠTorCh, P. \& Teller, L. 1995. Generalized graptolite zonal sequence defining Silurian time intervals for global paleogeographic studies. Lethaia $\mathbf{2 8}, 137-8$.

Legrand, PH. 1993. A propos d' un Niveau à Neodiplograptus dans le Silurien inférieur a l' est de Ouallene, Asejrad (Sahara Algérien). Implications Stratigraphiques et Paléogéographiques. In 118 Congrès national des Sociétés historiques et scientifiques, 4 éme colloque sur la Géologie africaine, Pau, 409-24.

Lendínez González, A., Tena-Dávila Ruiz, M., Bascones Alvira, L., Martín Herrero, D. \& La Moneda González, E. 1981. Memoria explicativa de la Hoja no 540 (Checa) del Mapa Geológico de España a escala 1:50000 (Segunda Serie). Instituto Geológico y Minero de España, 63 pp.

LenZ, A. C. \& Chen X. 1985. Graptolite distribution and lithofacies: some case histories. Journal of Paleontology 59, 636-42.

Lenz, A. C., Jin, J., McCracken, A. D., Utting, J. \& Westrop, S. R. 1993. Paleozoic Biostratigraphy. Geoscience Canada 20(2), 41-73.

Lotze, F. 1929. Beiträge zur Geologie der westlichen mediterraneangebiete 3. Stratigraphie und Tektonik des keltiberischen Grundgebirges (Spanien). Abhandlungen der Gesellschaft der Wissenschaften zu Göttingen, Mathematisch-Physikalische Klasse (neue Folge) 14(2), 143-462.

LOYDELL, D. K. 1991. The biostratigraphy and formational relationships of the upper Aeronian and lower Telychian (Llandovery, Silurian) formations of western mid-Wales. Geological Journal 26, 209-44.

LOYDELL, D. K. 1992-93. Upper Aeronian and lower Telychian (Llandovery) graptolites from Western Mid-Wales. Monograph of the Palaeontographical Society, London: Part 1, 1-55, pl. 1 (pub. no. 589, part of vol. 147); Part 2, 56-180, pls 2-5 (pub. no. 592, part of vol. 147).

LOYDELL, D. K. 1994. Early Telychian changes in graptoloid diversity and sea level. Geological Journal 29, 355-68.

Loydell, D. K. \& CAVE, R.1993. The Telychian (Upper Llandovery) stratigraphy of Buttington Brick Pit, Wales. Newsletter in Stratigraphy 29, 91-103.

Loydell, D. K., Štorch, P. \& Bates, D. E. B. (in press). Revision of the Silurian graptolite genus Retiolites. Palaeontology 40(3).

Menéndez Puget, L. 1928. Sobre los graptolitos de Sierra Menera. Boletín de la Real Sociedad Española de Historia Natural 28(6), 307.

Mu, E. Z., Boucot, A. J., Chen, X \& Rong, J. Y. 1986. Correlation of the Silurian Rocks of China (A Part of the Silurian Correlation for East Asia). Geological Society of America Special Paper 202, 1-80.

OCZLON, M. S. 1992. Examples of Palaeozoic contourites, tempestites and turbidites - classification and palaeogeographic approach. Heidelberger Geowissenschaftliche Abhandlungen 53, 57-159. 
Paris, F., Rickards, R. B. \& SkeVington, D. 1980. Les assemblages de graptolites du Llandovery dans le synclinorium du Ménez-Bélair (Massif Armoricain). Géobios 13, 153-71, pls 1-2.

PAskevicius, J. 1986. Assemblages of Silurian graptolites in various facies of the East Baltic region. In Palaeoecology and Biostratigraphy of Graptolites (eds C. P. Hughes and R. B. Rickards), pp. 237-45. Geological Society Special Publication no. 20.

Philippot, A. 1950. Les Graptolites du Massif Armoricain. Étude Stratigraphique et Paléontologique. Mémoires de la Société Géologique et Minéralogique de Bretagne $\mathbf{8}$, $1-295$.

PhilipPot, A. \& RibA, O. 1952. Sur la faune graptolitique de la Sierra d' Albarracín (Chaine Ibérique). Comptes Rendus Sommaires des Séances de la Société Géologique de France 1952(5), 74-5.

Portero, J. M. 1983. Memoria explicativa de la Hoja no 565 (Tragacete) del Mapa Geológico de España a escala 1:50000 (Segunda Serie). Instituto Geológico y Minero de España, 89 pp.

Portero, J. M., Olivé, A. \& Ramírez del Pozo, J. 1975. Memoria explicativa de la Hoja no 636 (Villar del Humo) del Mapa Geológico de España a escala 1:50000 (Segunda Serie). Instituto Geológico y Minero de España, $48 \mathrm{pp}$.

PRIBYL, A. 1945. O stredoevropských monograptech z rodu Spirograptus Gurich. Rozpravy II. Trídy Ceské Akademie 45, 1-46, pls 1-11.

Riba ARderiú, O. 1959. Estudio geológico de la Sierra de Albarracín. Monografias del Instituto "Lucas Mallada" de Geología (CSIC) 16, 1-283.

RickARDS, R. B. 1976. The sequence of Silurian graptolite zones in the British Isles. Geological Journal 11, 153-88.

Rickards, R. B., Brussa, E. D., Toro, B. A. \& Ortega, G. C. 1996. Ordovician and Silurian graptolite assemblages from Cerro del Fuerte, San Juan Province, Argentina. Geological Journal 31, 101-22.

RoBARDET, M. \& Doré, F. 1988. The Late Ordovician diamictic formations from southwestern Europe: north-Gondwana glaciomarine deposits. Palaeogeography, Palaeoclimatology, Palaeoecology 66, 19-31.

RodríGUEZ-NúÑEZ, V.M., GUTIÉRREZ-MARCO, J.C. \& SARMiENTO, G. 1989. Rasgos bioestratigráficos de la sucesión silúrica del Sinclinal del Guadarranque (provincias de Cáceres, Badajoz y Ciudad Real). COL-PA 42, 83-106.

Romariz, C. 1962. Graptolitos do Silúrico Portugues. Revista da Faculdade de Ciencias de Lisboa, Série C 10(2), $115-312$

Romariz, C. 1969. Graptolitos silúricos do Noroeste Peninsular. Comunicaçôes dos Serviços Geológicos de Portugal 53, 107-55.

SACHER, L. 1966. Stratigraphie und Tektonik der nordwestlichen Hesperischen Ketten bei Molina de Aragón/Spanien. Teil 1: Stratigraphie (Paläozoikum). Neues Jahrbuch für Geologie und Paläontologie Abhandlungen 124, 151-67.

San José, M. A. De, Rábano, I., Herranz, P. \& GutiérrezMarco, J. C. 1992. El Paleozoico Inferior de la Zona Centroibérica meridional. In Paleozoico Inferior de IberoAmérica (eds J. C. Gutiérrez-Marco, J. Saavedra and I. Rábano), pp. 505-21. Universidad de Extremadura, 630 pp.

SCHAUER, M. 1967. Biostratigraphie und Taxonomie von Rastrites (Pterobranchiata, Graptolithina) aus dem anstehenden Silur Östthuringens und desVogtlandes. Freiberger Forschungshefte, Reihe C 213, 171-99, pls 1-6.
SCHAUER, M. 1971. Biostratigraphie und Taxionomie der Graptolithen des tieferen Silurs unter besonderer Berücksichtigung der tektonischen Deformation. Freiberger Forschungshefte, Reihe C 373, 1-185, pls $1-45$.

ŠTORCH, P. 1994. Graptolite biostratigraphy of the Lower Silurian (Llandovery and Wenlock) of Bohemia. Geological Journal 29, 137-65.

ŠTORCH, P. \& LOYDELL, D. K. 1992. Graptolites of the Rastrites linnaei Group from the European Llandovery (Lower Silurian). Neues Jahrbuch für Geologie und Paläontologie, Abhandlungen 184, 63-86.

ŠTORCH, P. \& PASAVA, J. 1989. Stratigraphy, chemistry and origin of the Lower Silurian black graptolitic shales of the Prague Basin (Barrandian, Bohemia). Vestník Ústredního ústavu geologického 64, 143-62.

Toghill, P. \& Strachan, I. 1970. The graptolite fauna of Grieston Quarry, near Innerleithen, Peebleshire. Palaeontology 13, 511-21, pls 103-5.

TöRNQUIST, L. 1892. Undersokningar ofver Siljansomradets graptoliter. II. Lunds Universitets Arsskrifter 26, 1-33, pls $1-2$.

TöRnquist, L. 1907. Observations on the genus Rastrites and some allied species of Monograptus. Lunds Universitets Arsskrifter, Afd 2, 3(5), 1-22, pls 1-3.

TORRUBiA, J. 1754. Aparato para la Historia Natural Española. Tomo Primero. Imprenta de los Herederos de Don Agustín de Gordejuela y Sierra, Madrid, $234 \mathrm{pp}$.

Tricalinos, J. 1928. Untersuchungen über den Bau der Keltiberischen Ketten der nordöstlichen Spaniens. Zeitschrift der Deutschen Geologischen Gesellschaft 8(4), 409-82.

TRURNIT, P. 1967. Paläozoikum und mesozoischer Rahmen im SE-Teil der Sierra del Tremedal (Hesperische Ketten/Spanien). Neues Jahrbuch für Geologie und Paläontologie Abhandlungen 127, 349-65.

Truyols, J. \& Julivert, M. 1983. El Silúrico en el Macizo Ibérico. In Libro Jubilar J.M. Ríos. Geología de España, Tomo 1 (ed. J. A. Comba), pp. 246-65. Instituto Geológico y Minero de España, 656 pp.

Turner, J. C. M. 1960. Faunas graptolíticas de América del Sur. Revista de la Asociación Geológica Argentina 14(1-2), 5-180.

Verneuil, E. \& Collomb, E. 1853. Coup d'oeil sur la constitution géologique de quelques provinces de l' Espagne. Bulletin de la Société Géologique de France 10(2), 61-176.

Viallard, P. \& Philippot, A. 1967. Découverte du Silurien (Gothlandien) dans la province de Cuenca (Espagne). Comptes Rendus Sommaires des Séances de la Société Géologique de France 1967(8), 364-6.

VIllanova Y PIERA, J. 1870. Ensayo de una descripción geognóstica de la provincia de Teruel en sus relaciones con la agricultura de la misma. Memoria de la Junta General de Estadística, Madrid, 312 pp.

VillenA, J. 1976. Estudio geológico de un sector de la Cordillera Ibérica comprendido entre Molina de Aragón y Monreal (provincias de Guadalajara y Teruel). Paleozoico. Boletín Geológico y Minero 87(4), 329-54.

WILLIAMS, S. H. 1983. The Ordovician-Silurian boundary graptolite fauna of Dob's Linn, southern Scotland. Palaeontology 26, 605-39, pl. 66.

Zalasiewicz, J. 1994. Middle to late Telychian (Silurian: Llandovery) graptolite assemblages of central Wales. Palaeontology 37, 375-96. 